\author{
Anna Gruczyńska \\ University of Lodz \\ Faculty of Economics and Sociology \\ e-mail: a.gruczynska@o2.pl
}

\title{
The Human Development Index as an indicator of economic development. An assessment based on a comparative case study of five European Post-Socialist Countries
}

\begin{abstract}
The aim of the paper is to evaluate the Human Development Index (HDI) as an indicator of economic development. The analysis is based on case studies of five post-socialist countries: the Czech Republic, Estonia, Hungary, Lithuania, and Poland. To carry out the assessment of the HDI, two approaches are employed. The first involves comparing the HDI values to seventeen other indicators related to different aspects of development chosen with reference to Amartya K. Sen's approach. The second approach refers to public opinion surveys provided by the Eurobarometer and the European Quality of Life Survey programs.

In the light of the analysis, it can be said that the HDI is a fairly good measure of economic development. However, certain important dimensions which have a significant impact on people's living conditions are neglected. Knowing about Sen's influence on the creation of the HDI and the emphasis he put on the relationship between democracy and development, it may be surprising that such neglected dimensions include the state of democracy.
\end{abstract}

Keywords: economic development, Human Development Index, case study, post-socialist counties

JEL Classification: I32, O52, O57 


\section{Introduction}

Economic development has been investigated by economists for decades, and it continues to be one of the most discussed topics in the field. A significant part of the ongoing debates pertains to indicators of economic development employed to evaluate and compare countries' economic performance. One of the most common measures is the Human Development Index (HDI), inspired by Amartya K. Sen's approach to economic development and popularized by the United Nations Development Program (UNDP) yearly reports.

The aim of the article is to assess the HDI as a measure of economic development by conducting a comparative case study of five Central European post-socialist countries: the Czech Republic, Estonia, Hungary, Lithuania, and Poland. To carry out an adequate assessment of the HDI, two approaches are employed. The first involved comparing the HDI values to seventeen other indicators related to different aspects of development chosen with reference to Sen's approach. In the case of each of these indicators, the performance of the chosen countries was ranked from the best to the poorest on a scale from 1 to 5 . These ranks were then summed up so that the results were comparable with the ranking based on the HDI. The second approach refers to public opinion surveys provided by the Eurobarometer and the European Quality of Life Survey programs. Three questions were chosen for this concerning the respondents' overall happiness, satisfaction with life, and satisfaction with national democracy. Opinion polls are an important source of subjective feelings about life in a given country, and as such they give complementary insight into the level of human development in the state.

The analysis supports a conclusion that the HDI may be regarded as a fairly good indicator of human development; however, there are certain important dimensions which have an influence on living conditions, which it does not represent. One of them is the state of democracy.

The analysis is concerned with the period between 2005 and 2015.

\section{Defining economic development. The essence of the approach of Amartya K. Sen}

As a natural starting point to talk about measures of economic development, it is necessary to define how this notion is understood. It must be emphasized that the concept of economic development is wider than the category of economic growth. The former pertains to the process of improving the quality of the lives of all the people and their capabilities by raising their level of living, self-esteem and freedom. The latter refers to an increase in national or per capita income, when the production of goods and services rises, causing the average income to increase (Perkins, 2013, pp. 13-14). These three values represent common aims that all individuals and societies seem to look for and regard as the most fundamental needs. The last of them, i.e., freedom, relates to a broad range of choices that individuals may enjoy, coupled with minimizing constraints in the pursuit of their self-devel- 
opment. Freedom is the variety of alternatives enabling the fulfillment of wants and needs through choices in line with their preferences (cf. Todaro \& Smith, 2015, p. 22-23).

While referring to the difference between development and growth, it should also be noted that an increase in income may be used not for the welfare of the citizens, but to reinforce the power of the government through such means as increased military spending, or for personal gains achievable with corruption. Moreover, the additional resources and income might be invested in further growth, and thus citizens will not be able to consume the gains until later. And lastly, those who are already relatively well-off might get all or most of the profits, due to the issue related to income distribution.

There is no single determinant hindering development, and there is no single policy that will lead to successful economic performance. The process of economic development is influenced by multiple factors, including not only the global economic and political climate, but also the planet's physical climate, advancements in technology, or healthcare. This makes any generalization difficult, but it can be pointed out that the theories of development lie on a spectrum that stretches from concepts which emphasize the environmental factors to those that underline the role of human activity (Dzionek-Kozłowska \& Matera, 2016, p. 8).

Sen's approach to economic development, which was the main source of inspiration for the creation of the HDI, is closer to the institutional end of the spectrum. His core message is that development should be regarded as an increase in freedom for a person to lead the life he or she values and would like to lead. The proper institutional framework is a key factor allowing someone to achieve such an end. Individual capabilities are dependent on economic, social and political arrangements. Institutional support based on the democratic, legal and free market systems, and education and health care arrangements, seems to be necessary to promote development as both the state and the citizens have far-reaching influence in reinforcing and protecting people's capabilities. This perspective recognizes people as active participants in forming their fate, instead of being only a passive beneficiary of development programs imposed on them.

There are many forms of "unfreedoms," as they are called by Sen (2000, p. 15). One of them is famine, which restricts people from the basic freedom to survive. Another form is the denial of basic political and civil rights, and this might be even more important to economic development. When people have more freedom, they have more initiative as well as an impact on the world and its changes, and therefore on development. Sen admits that low income can be connected with the low capabilities of individuals, as it can be the cause of sicknesses, illiteracy and higher mortality. However, he points out that it is more beneficial to view the problem broadly from the perspective of the deprivation of capabilities rather than exclusively as an issue of low incomes (2000, pp. 21-23).

Sen (2000, pp. 70-71) identified four broad factors, beyond poverty, that affect how well income can be converted into "the capability to live a minimally acceptable life." They are: (1) personal heterogeneities, including age, proneness to illness, and the extent of disabilities, (2) environmental diversities affecting the need for shelter, clothing, and fuel required by climatic conditions, (3) variations in social climate, such as the impact of crime, civil unrest, and violence, and (4) differences in relative deprivation, such as the extent to which being impoverished reduces one's ability to take part in the life of the greater community. According to Sen, economic development requires that the sources of "capability deprivation" that prevent people from having the freedom to live the lives they desire be alleviated. 


\section{Human Development Index. Its origin and evolution}

The extension of Amartya K. Sen's ideas is the Human Development Index, created by the Human Development Reports Office of the United Nations Development Programme (UNDP). The Index was incorporated into the Human Development Report, which was devised and launched in 1990 by a team of researchers led by Pakistani economist Mahbub ul Haq. The authors of the report wanted to propose a measurement of development that did not solely rely on growth in capital stocks and the growth rate of GDP per capita. Before the 1960s, it was commonly assumed that well-being would follow automatically from economic growth; the distribution of welfare was neglected, and its omission was defended with the "trickle down" idea. Soon it was proven, however, that income could not be the only measure of development as it was not able to alleviate mass poverty. Researchers started to use other indicators, relating to issues such as mortality, morbidity, or urbanization related to GDP per capita in a series of regressions. This enabled the creation of thresholds for development, below which a country was deemed as underdeveloped, and above it, as developed.

Nevertheless, there still was no index that would combine these multiple indicators to show the overall situation of a country and its development, analogous with income. Designing an index that would measure development in a satisfactory manner posed multiple issues. One of those concerned the decision regarding which indicators to include and which to leave out. The matter with many comprehensive indices is that the more indicators they include, the less transparent and relevant to everyday experiences they are. The efforts resulted in the creation of the Human Development Index (HDI), which aimed to measure development not as the expansion of goods and wealth, but as broadening the range of choices available to people (UNDP, 1990, p. 105). In this essential aspect, the index draws from Sen's thinking, the capabilities approach, and the idea of development as freedom.

The index was calculated in three steps. Firstly, the measure of deprivation that a country undergoes is determined in three basic variables: life expectancy $\left(X_{1}\right)$, the rate of literacy $\left(X_{2}\right)$, and (the log of) real GDP per capita $\left(X_{3}\right)$. Next, a minimum and a maximum value are defined for each of these variables, depending on the actual values noted in each particular country. Then the countries are placed in the range between zero and one, according to the difference between the maximum and the minimum. $I_{i j}$ is the deprivation indicator for country $j$ with respect to variable $I$, and formulated as:

$$
I_{i j}=\frac{\left(X_{i j}-\min X_{i j}\right)}{j}
$$

Secondly, an average deprivation indicator was formulated by taking a simple average of the three indicators:

$$
I_{j}=\frac{1}{3} \sum_{i=1}^{3} I_{i j}
$$


Thirdly, the Human Development Index was constructed as one minus the average deprivation index:

$$
H D I_{j}=\left(1-I_{j}\right)
$$

This formulation of the index was not ideal, which was noted by the authors themselves. They pointed to two issues, the first being disparities between males and females, and the second being the deficiencies in the statistics. Regarding the problem with gender differences, after comparing two gender-specific HDIs, the authors noticed that (1) as the country moves up the scale, the female index steadily approaches and overtakes the male index, and (2) in countries with similar HDIs, there is an immense variation in the female-male disparity. Their conclusion was that country averages may hide seriously large gender disparities, and this problem should be studied more closely.

The issue of deficiencies in statistics results from the fact that the first Report depended on data already available, which restricted the scope and depth of the analysis. The data in many countries was inadequate, and for that reason, many variables were omitted from the investigation (UNDP 1990, p. 112). Another problem faced by the authors of the index was incomplete country coverage. A third of the analyzed countries lacked a third of some of the 120 indicators, which demonstrated the enormous deficiency in key human development indicators. What is more, some indicators might not have been reliable, because they are only very broad approximations, such as literacy or maternal mortality. Furthermore, there comes the issue of timeliness. Some indicators, such as income or poverty, come from complicated surveys which are not performed often. This results in data that might not be up-to-date.

The subsequent Human Development Report, published in 1991, began to improve those shortcomings. Better estimates of the three main variables - longevity, knowledge and decent living standards - as well as greater sensitivity to male-female and income distribution differences, and the calculation of HDI over time, were significant improvements. The overall formulas for the three essential variables of the Index and the Index itself can be presented as:

$$
\text { Life Expectancy Index }=\frac{\text { Life Expectancy }-25}{85-25},
$$

$$
\text { Education Index }=\frac{2}{3} A L I+\frac{1}{3} G E I \text {, where: }
$$

$A L I($ Adult Literacy Index $)=\frac{A L R-0}{100-0} ; A L R=$ Adult literacy rate $(\%)$

$G E I($ Gross Enrollment Index $)=\frac{C G E R-0}{100-0} ; C G E R=$ Combined gross enrollment rate $(\%)$ 


$$
\begin{gathered}
G D P=\frac{\log \left(G D P_{\text {per capita }}\right)-\log (100)}{\log (40000)-\log (100)}, \\
H D I=\frac{1}{3} L E I+\frac{1}{3} E I+\frac{1}{3} G D P .
\end{gathered}
$$

Therefore, the Human Development Index is a tool that enables the evaluation of the distance between a country and the benchmark of complete human development set by the UNDP. Complete human development is indicated by the upper values of the three dimensions of the HDI: life expectancy, education, and living standards (GDP per capita).

The aforementioned methodology was used in the Reports until 2010, when it was re-adjusted. From that year on, the calculation of the Index is established in two steps (UNDP 2010, p. 216). Firstly, subindices are created for each of the following five dimensions: life expectancy, mean years of schooling, expected years of schooling, combined education index, and income per capita (PPP in USD). The indicators need to be set into indices between 0 and 1, and in order to achieve this, maximum and minimum values (goalposts) are established. The maximum values are set to the actually observed maximum values of the indicators in the countries in the related time series, in the case of the 2010 Report, it was the years 1980-2010. The minimum values are set at "natural zeros", or levels that are necessary for a society to survive over time.

After defining the minimum and maximum values, the indices are computed from the formula:

$$
\text { Dimension index }=\frac{\text { actual value }- \text { minimumvalue }}{\text { maximumvalue }- \text { minimum value }} .
$$

From those, the Human Development Index is computed as the geometric mean of the three dimension indices:

$$
H D I=I_{\text {Life }}^{1 / 3} \cdot I_{\text {Education }}^{1 / 3} \cdot I_{\text {Income }}^{1 / 3}
$$

The enhancement in the methodology, and the use of new indicators and new formulas, created considerable changes. Adopting the geometric mean for calculating the HDI resulted in lower index values, with the biggest changes appearing in countries with uneven development across dimensions.

That year, the Report also contained a variation of the HDI called the Inequality-adjusted Human Development Index, which addressed crucial development factors not directly reflected in the HDI. The new index adjusts the HDI for inequality in the distribution of each dimension across the population. It is a geometric mean of geometric means, computed across the population separately for every dimension, and accounts for inequalities in the dimensions by "discounting" every dimension's average depending on its level of inequality. If there is no inequality in the population, the IHDI equals the HDI, and as inequality increases, the IHDI becomes less than the HDI. According to this, the IHDI is the real level of human development, and the HDI could be seen as showing the "po- 
tential" human development that could be reached if there was no inequality. This "loss" of potential human development, caused by inequality, is presented as the difference between the HDI and the IHDI, conveyed as a percentage.

The changes made to the Index from 1990 until the new version in 2010 are summarized in Figure 1.

As one might expect with any attempt to measure the complexity of the world, the Human Development Index has received a fair dose of commentary and criticism, despite also being recognized as a step forward in the measurement of development and a contribution to creating a prominent place for the concept of human development in research and intellectual discourse (Sagar \& Najam, 1998, p. 250).

The critical opinions were aimed at challenging the computation of the index, the fact that the three indicators of human development were given equal weights (Kelley, 1991, p. 315-319; Sagar and Najam, 1998, pp. 251-252; Noorbakhsh, 1998, p. 591), the narrowness of the dimensions that describe capabilities in the HDI (Klugman et al., 2011) and, in particular, the lack of any environmental indicators of development and no consideration for the sustainability dimension of human development (Sagar and Najam, 1998, pp. 251, 263). They also criticised the fact that the HDI measured human development with a mixture of stock and flow variables, as well as inputs and outputs (Klugman et al., 2011, p. 259; Hou et al., 2015, p. 333), and focused on quantities not qualities of certain important dimensions of human development, such as education and healthcare (Klugman et al., 2011, p. 260; Kovacevic, 2010, p. 7). Some of the problems were addressed by the changes incorporated in the index in 2010; however, the others remain unsolved. 


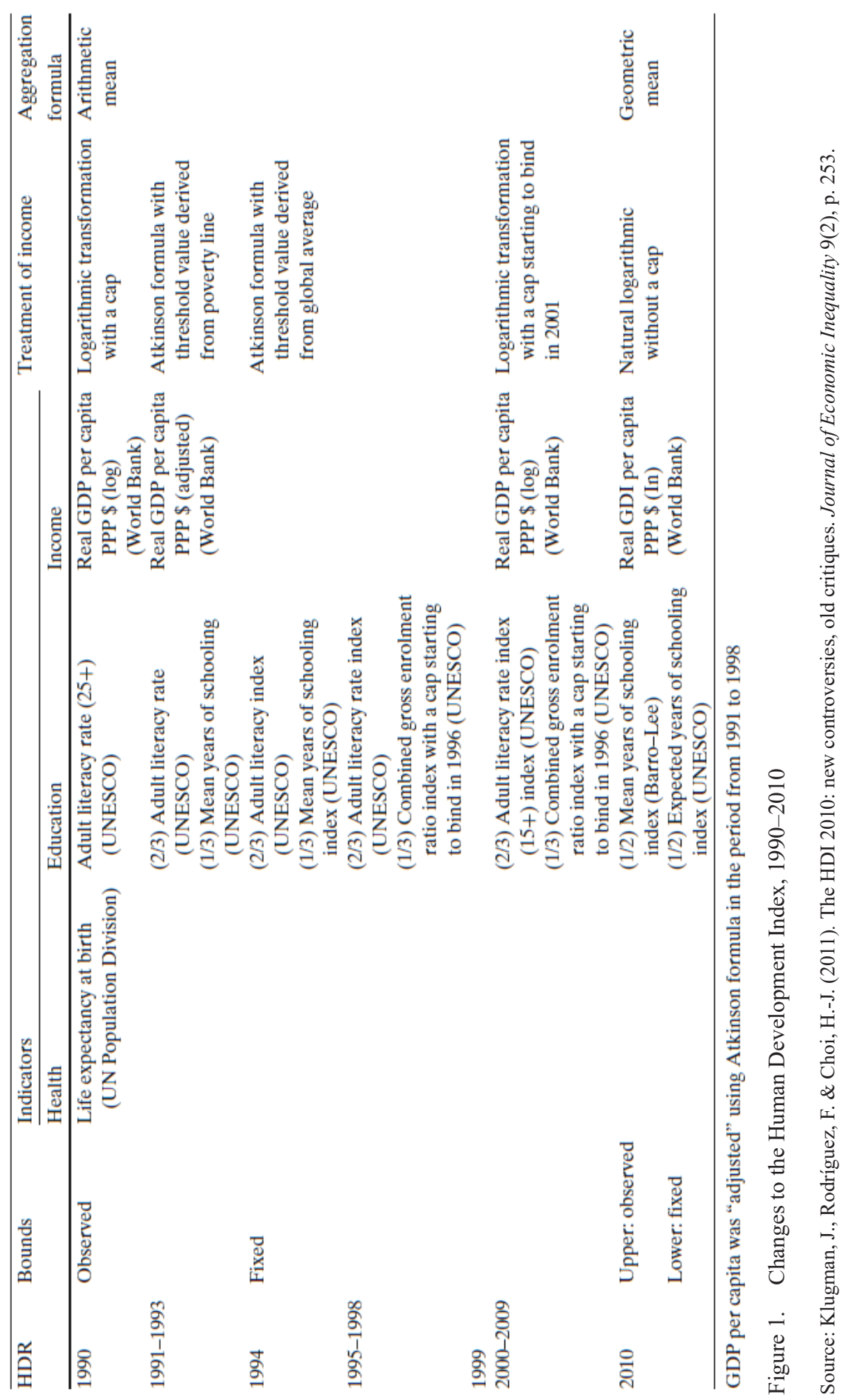




\section{Measuring economic development in five post-socialists countries}

In order to examine the Human Development Index as a satisfactory measure of human development, five countries were chosen for the analysis: the Czech Republic, Estonia, Lithuania, Hungary, and Poland. This choice was motivated by the historical processes of the $20^{\text {th }}$ century which connect all those countries. They were formerly part of the Eastern bloc, and were controlled by the Soviet Union in many aspects, especially Estonia and Lithuania, which were Soviet Republics. All these states underwent a process of transformation, starting in the 1990s and lasting well into the 2000s. They also later became members of the European Union in 2004, harmonizing their legal regulations, standards, and norms with those of the European Union community on multiple levels. A comparison with the other EU member states will offer a valuable insight, but it is necessary to keep in mind the differences in political, economic and social conditions of the various countries. For that reason, the analysis is performed for these five states of comparable conditions, with reference to the other member states of the EU.

The analysis is concerned mainly with the period between years 2004 and 2015 .

\subsection{The HDI in the Czech Republic, Estonia, Lithuania, Hungary, and Poland}

As previously stated, the computation of the Index underwent major changes in 2010, thus making the Index data from before 2010 and after 2010 incomparable. However, the United Nations Development Programme provides updated indices for the years before 2010, recalculated with the use of the new method. Thanks to this, a country's performance can be compared throughout the years.

Figure 2 below presents the values of the Human Development Index observed in the chosen countries during the period from 2004 to 2015.

To start with, during the given period, all five countries noted steady growth regarding their Human Development Index values. It can be easily noticed that the Czech Republic had visibly higher HDI values from the beginning of the analyzed period in 2004. This sort of supremacy was considerable, as the country had an HDI of 0.84, while Hungary, Lithuania and Poland's values were below 0.8. In 2015, the Czech Republic nearly reached an HDI of 0.88 , while Estonia, which is in second place out of the chosen countries, was at a level of 0.865 . Initially, Lithuania established its position as third among the group but it was surpassed by Poland in 2010, which steadily achieved increasing HDI scores, and in 2015 it came close to the level of 0.86. Even though Hungary, Lithuania, and Poland started in 2004 from nearly the same positions, Hungary was the last out of the five countries in 2015, with a score short of 0.84 . It should be noted that what is Hungary's HDI now was the Czech Republic's value in 2004.

Figures 3 presents the extent of change in the HDI for the five countries in the period between 2004 and 2015. 


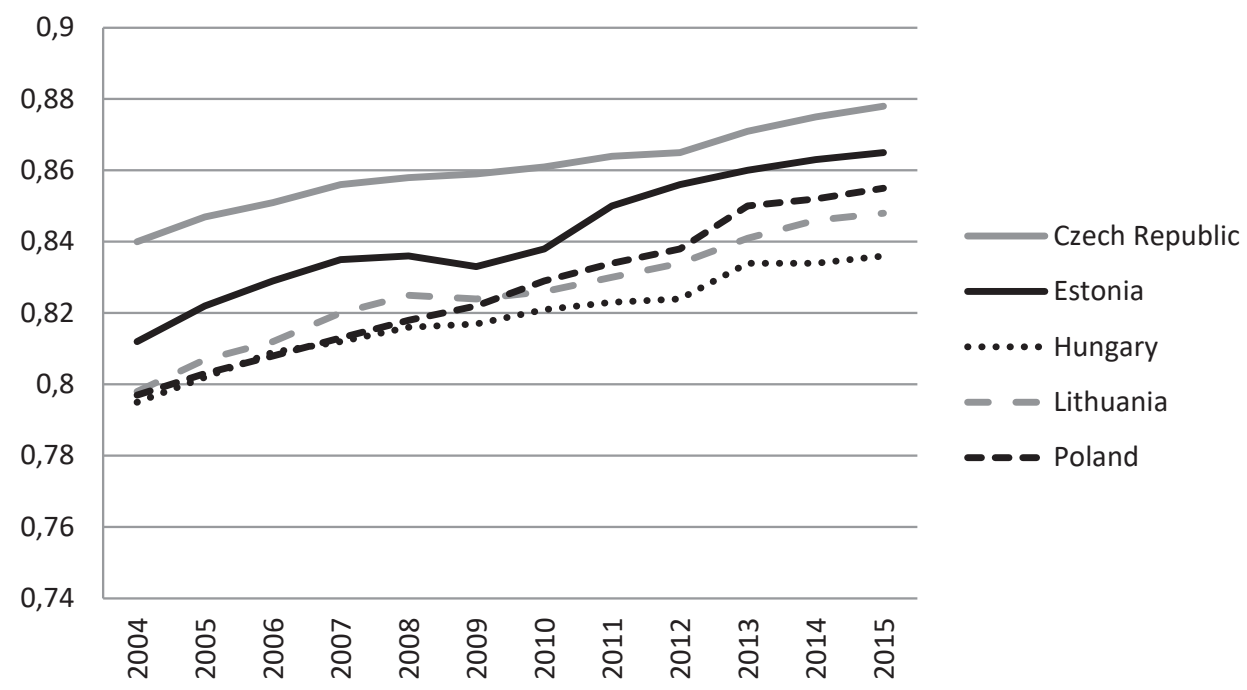

Figure 2. HDI changes in the years 2004-2015 in chosen countries

Source: United Nations, Human Development Data (1990-2015). http://hdr.undp.org/en/data

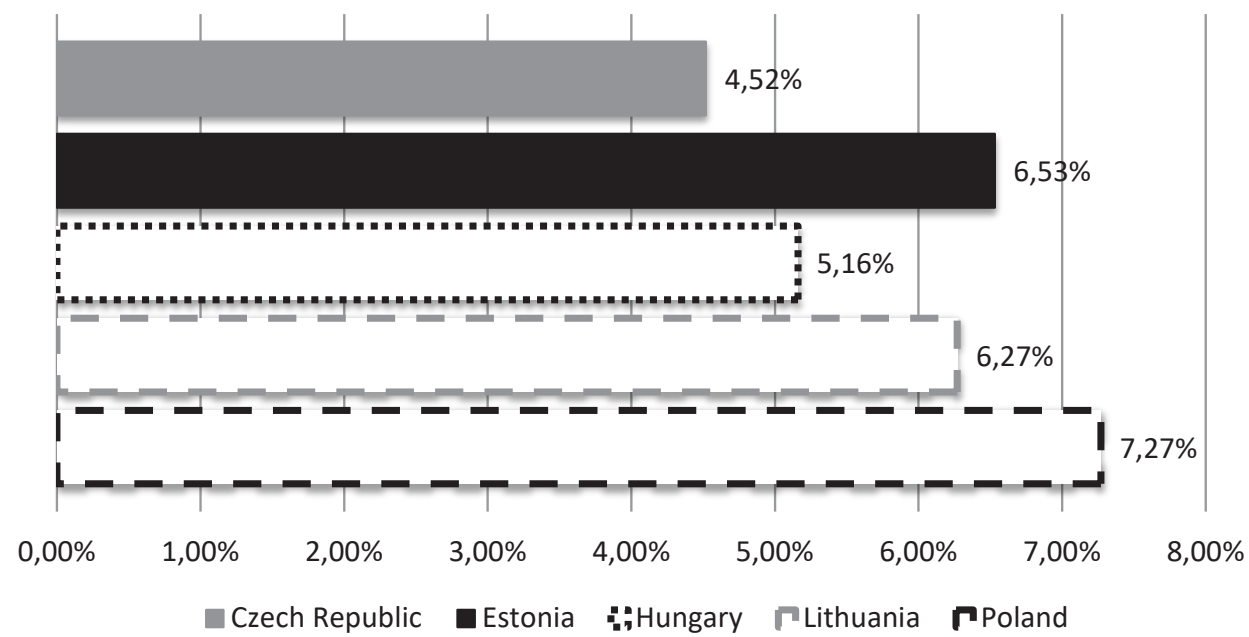

Figure 3. Percentage change of HDI 2004-2015

Source: Adapted from United Nations, Human Development Data (1990-2015). http://hdr.undp.org/en/data

Poland observed the biggest increase in the value of HDI, which grew by $7.27 \%$ throughout the 12-year period. This country also noted the highest average annual change of the index value $-0.61 \%$. Estonia and Lithuania had lower HDI growth than Poland, at $6.53 \%$ and $6.27 \%$ respectively, and their average annual change of the HDI value was around $0.5 \%$. During the twelve-year period, Hungary's value of the Index increased by $5.16 \%$, and even 
though it is not the smallest growth out of the five countries, the country remains the one with the poorest performance out of the group. The Czech Republic noted an HDI growth of $4.5 \%$, but it started out with a much higher HDI value, and this might explain the smaller and slower increase (around 0.4 percentage points per year on average).

In line with what was mentioned in previous chapters, the Human Development Index, although useful, shows only the potential human development that a country is capable of. Meanwhile, the Inequality-Adjusted Human Development Index (IHDI) shows the reality of human development, taking into consideration inequalities that may be present in a country. Unfortunately, the IHDI is available only for the years between 2010 and 2015. Nevertheless, an analysis of this shorter period is a worthy addition.

The IHDI values for the chosen countries are presented in Figure 4 below.

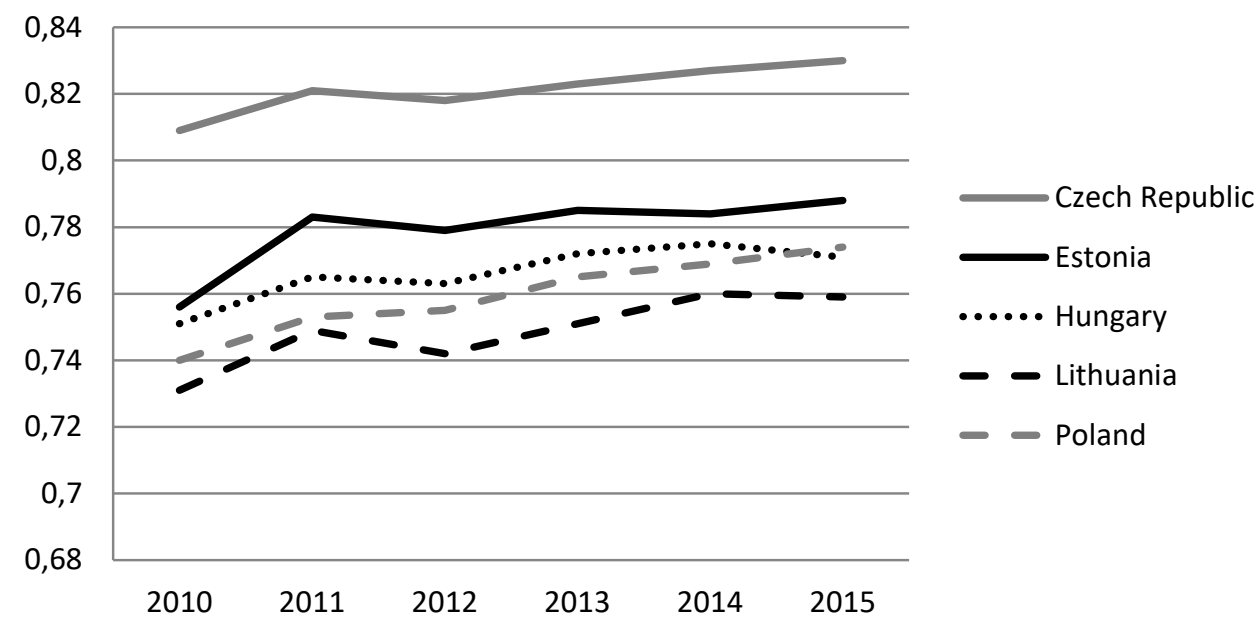

Figure 4. IHDI in the years 2010-2015 in chosen countries

Source: United Nations, Human Development Data (1990-2015). http://hdr.undp.org/en/data

In 2015, the countries held the same positions as they did regarding the regular HDI: the Czech Republic was in $28^{\text {th }}$ place, Estonia $30^{\text {th }}$, Hungary $43^{\text {rd }}$, Lithuania $37^{\text {th }}$, and Poland $36^{\text {th }}$. However, compared to Figure 2, there are many differences. The Czech Republic had a much better performance than the other countries, with values above the threshold of IHDI equal to 0.8, while out of the remaining four countries, only Estonia exceeded 0.78. Comparing the IHDI to HDI values, a particularly visible difference is the considerable advantage that the Czech Republic has over the other countries regarding IHDI, while in case of HDI, this advantage was not as large. In both indices, Estonia holds second place. The differences are visible in the next three countries' positions. For four years, Hungary was third, with Poland following, but in 2015 Poland took third place. Lithuania steadily remains the last out of the five regarding IHDI, while in case of HDI rankings, it surpasses Hungary, which performs better in the index that does not consider inequalities. A tentative con- 
clusion can be made at this point that Lithuania and Poland have more problems with inequality than the Czech Republic, Estonia, or Hungary, because these two countries perform worse in terms of IHDI than they do in HDI in comparison to the other three states.

To further assess the performance of each of the five countries according to the Human Development Index, the components of the Index can offer a valuable insight. UNDP offers values of the education, life expectancy, and income components for the years 2005 and 2010-2015. The values of the components for the chosen five countries are presented in Figures 5-7 below.

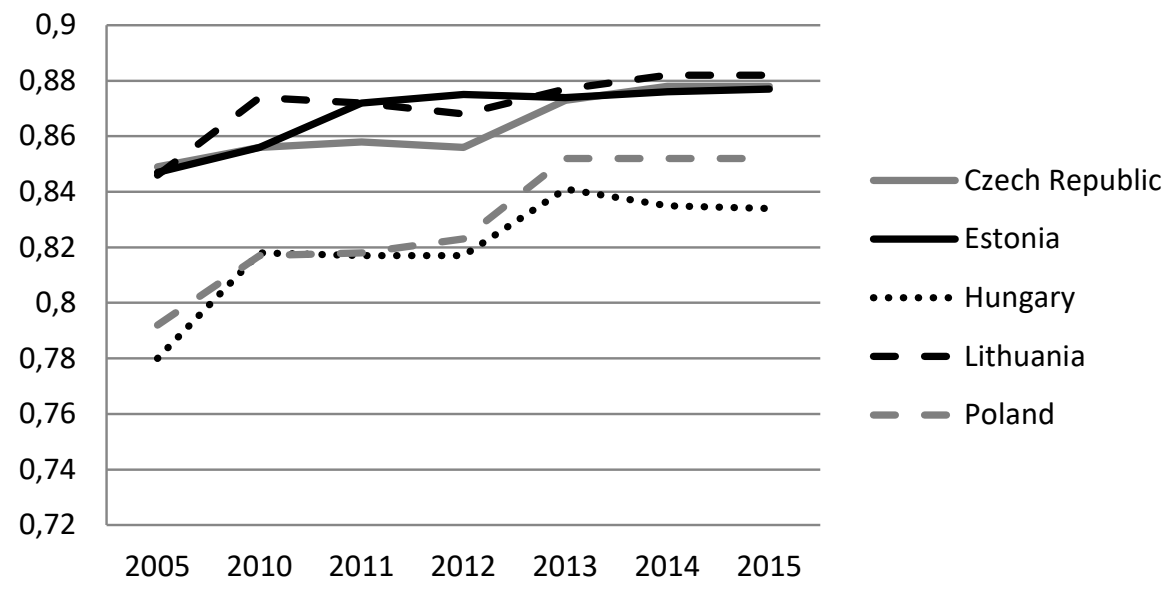

Figure 5. Education Index in the years 2005-2015 in the chosen countries

Source: United Nations, Human Development Data (1990-2015). http://hdr.undp.org/en/data

The Education Index is an average of the mean years of schooling (of adults) and expected years of schooling (of children), both expressed as an index obtained by scaling with the corresponding maxima. Regarding this index, presented in Figure 5 above, most of the chosen countries noted stagnation in recent years. The Czech Republic and Lithuania had nearly no change in results in 2014 and 2015, Estonia had very even Education Index values from 2011, while Poland has had the same results since 2013. Hungary is the exception in this case, because its Education Index value decreased from 2013.

As far as Life Expectancy Index is concerned, presented in Figure 6 above, all five countries have had steadily increasing results. In this matter, Lithuania is performing the worst, noting values significantly lower than the other countries. The Life Expectancy Index is life expectancy at birth expressed as an index using a minimum value of 20 years and a maximum value of 85 years. Life expectancy at birth itself has been growing in all five countries. In the Czech Republic, it increased from 75.8 years in 2004 to 78.8 years in 2015 (3 years). For Estonia, the value of this index increased from 72.2 years in 2004 to 77 years in 2015, which was the biggest change out of the five countries (an increase of 4.8 years). In Hungary, this increase was smaller, from 73 years in 2004 to 75.3 years in 2015 (2.3 years). For Lithuania, the result was an increase from 71.5 years in 2005 to 73.5 years in 2015 , and it was the smallest change out of the group, of only 2 years. For Poland, the index increased from 74.8 years in 2004 to 77.6 years in 2015 (2.8 years). 


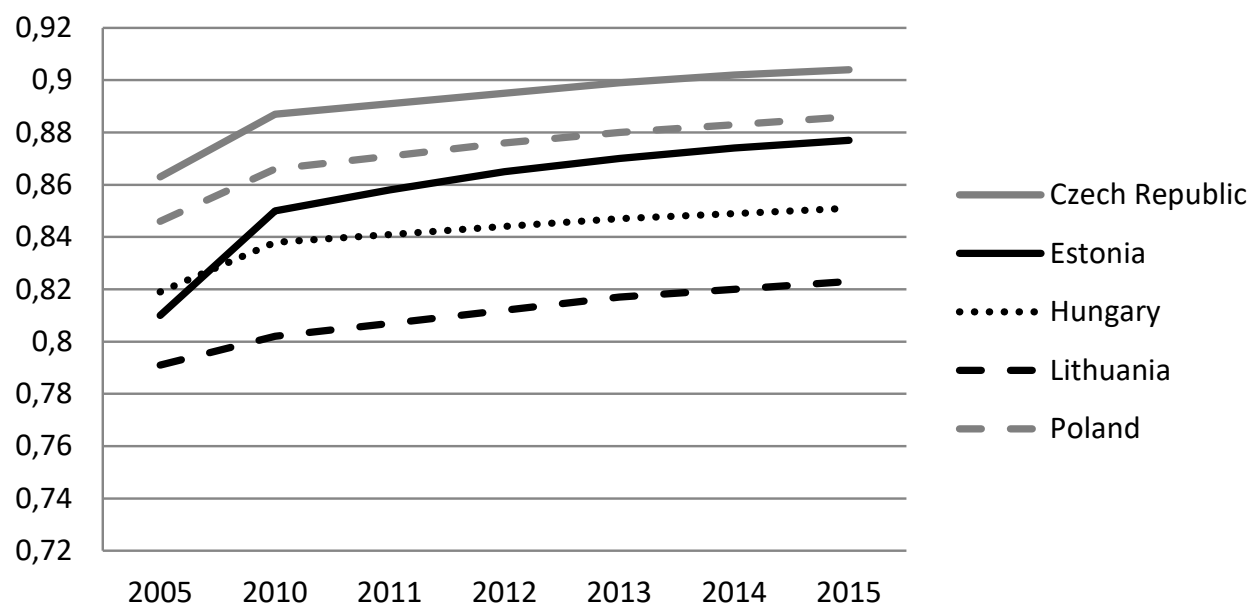

Figure 6. Life Expectancy Index in the years 2005-2015 in chosen countries

Source: United Nations, Human Development Data (1990-2015). http://hdr.undp.org/en/data

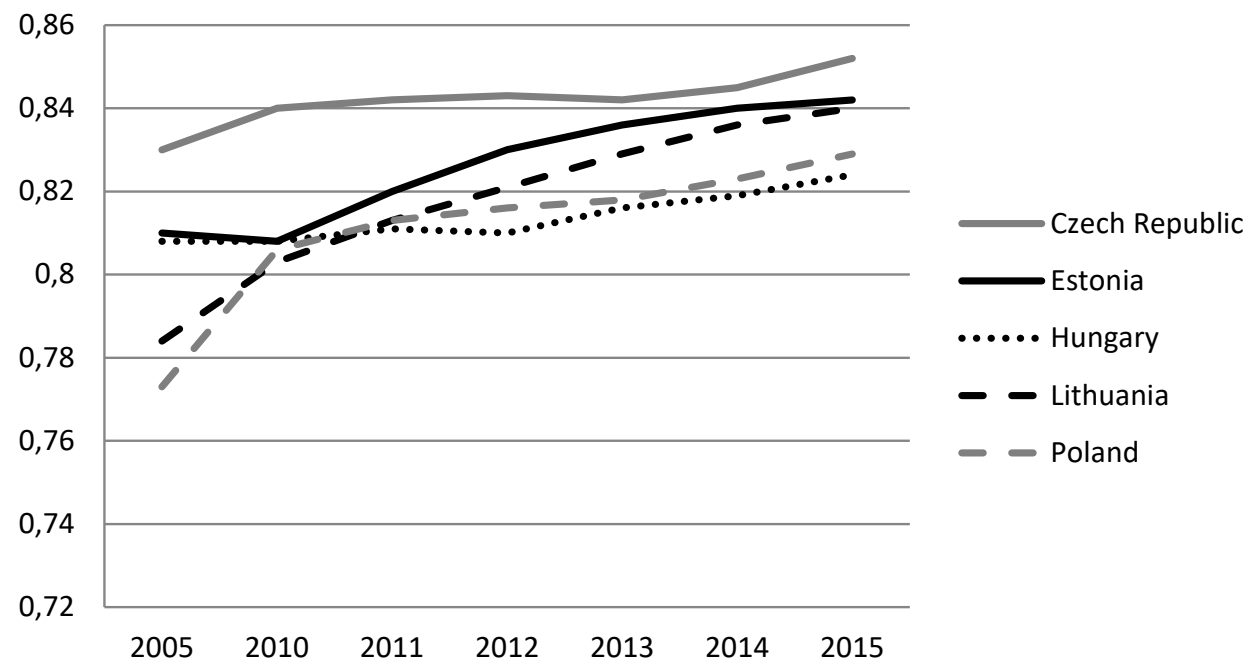

Figure 7. Income Index in the years 2005-2015 in chosen countries

Source: United Nations, Human Development Data (1990-2015). http://hdr.undp.org/en/data

The Income Index, for the most part, increased for all the chosen countries. The results are presented in Figure 7 above. The Income Index is Gross National Income per capita (2011 PPP International dollars, using the natural logarithm) expressed as an index using a minimum value of $\$ 100$ and a maximum value of $\$ 75,000$. As in previous cases, the Czech Republic had a visible advantage over the other four countries at the beginning, with Estonia and Hungary following, Lithuania next in line, and Poland as the one with 
the lowest result. Regarding this component, the most notable growth can be observed for Estonia, Lithuania, and Poland. During the analyzed period, Hungary fell from third place to last out of the five, with Poland climbing up from its initial rank as the last of the group, surpassing Hungary, although not by much. The Czech Republic remains the country with the highest income, with Estonia and Lithuania following, both with income achievements at a similar level.

Another subject to explore in this matter is which of the three components of the Index has the most impact on the result of the HDI itself for the chosen countries for the years 2005 and 2010-2015. In order to study this relationship, the correlation between each component and the respective Index value was calculated. The results are presented in Table 1 below, where the highest correlation was emphasized.

Table 1. Pearson correlation of HDI and Index components for chosen countries

\begin{tabular}{|l|l|c|}
\hline \multicolumn{1}{|c|}{ Country } & Component & Pearson correlation of HDI and Index component \\
\hline \multirow{4}{*}{ Czech Republic } & Education & $\mathbf{0 . 9 2 0 2 8 3 9 6 3}$ \\
\cline { 2 - 4 } & Life Expectancy & 0.825293467 \\
\cline { 2 - 3 } & Income & 0.784581816 \\
\hline \multirow{4}{*}{ Hungary } & Education & $\mathbf{0 . 9 7 5 1 4 0 3 4 5}$ \\
\cline { 2 - 3 } & Life Expectancy & 0.974641517 \\
\cline { 2 - 3 } & Income & 0.920809706 \\
\hline \multirow{4}{*}{ Lithuania } & Education & $\mathbf{0 . 9 8 4 0 8 5 9 4 5}$ \\
\cline { 2 - 3 } & Life Expectancy & 0.982942577 \\
\cline { 2 - 3 } & Income & 0.795553783 \\
\hline \multirow{4}{*}{ Poland } & Education & 0.934132414 \\
\cline { 2 - 3 } & Life Expectancy & 0.992037839 \\
\cline { 2 - 3 } & Income & $\mathbf{0 . 9 9 2 1 4 0 9 2 6}$ \\
\hline \multirow{3}{*}{ All five countries } & Education & 0.968289533 \\
\cline { 2 - 3 } & Life Expectancy & $\mathbf{0 . 9 9 3 2 7 1 8 3 1}$ \\
\cline { 2 - 3 } & Income & 0.9721627 \\
\cline { 2 - 3 } & Education & 0.730382378 \\
\cline { 2 - 3 } & Income & 0.75076628 \\
\hline
\end{tabular}

Source: Adapted from United Nations, Human Development Data (1990-2015). http://hdr.undp.org/en/data

As one might expect, the correlation of each component and the HDI value was positive and strong in the case of all countries, since the Pearson correlation results were always above 0.7 . For three out of five countries, the correlation was highest between the HDI and the Education Index - this was the case of the Czech Republic, Estonia, and Hungary. As for Lithuania and Poland, the highest correlation was observed with the Income Index and Life Expectancy Index, respectively. The values of the correlation indices in both cases exceed 0.9. When it comes to all the countries, the correlation was strongest for the HDI and the Income Index. The index second-most correlated with the HDI was Life Expectancy, which was true for the Czech Republic, Estonia, Hungary, Lithuania, as well as cumulative calculations for all countries. In the case of Poland, the highest correlation after Life Expectancy was with the Income Index. For the Czech Republic, Estonia, and 
Hungary, the weakest correlation of the HDI was observed with Income Index, while in the case of Lithuania and Poland with the Education Index. Regarding all five countries altogether, the weakest correlation for the HDI was noted with the Education Index.

\subsection{Measuring human development with a set of indicators provided by Eurostat}

To attempt an investigation into whether the Human Development Index describes the reality well enough, and therefore if it is a satisfying extension of Sen's philosophy, the chosen countries' development was analyzed with the use of the sum of ranks method.

To start with, seventeen indices that measure different aspects of human development were chosen for the analysis of the five countries. These indices are presented in Table 2.

Table 2. Description of the chosen indexes

\begin{tabular}{|c|c|c|}
\hline Index & Description & Justification \\
\hline $\begin{array}{l}\text { Healthy } \\
\text { life years } \\
\text { at birth }\end{array}$ & $\begin{array}{l}\text { The number of years that a person } \\
\text { at birth is expected to live in a healthy } \\
\text { condition (the average for males and fe- } \\
\text { males); a healthy condition is defined } \\
\text { by the absence of limitations in functio- } \\
\text { ning or of a disability. }\end{array}$ & $\begin{array}{l}\text { Longer predicted healthy life years } \\
\text { mean more years in good health, when } \\
\text { people are able to make use of their fre- } \\
\text { edoms and lead a life they value, witho- } \\
\text { ut bearing the burden of illnesses. }\end{array}$ \\
\hline $\begin{array}{l}\text { Very good } \\
\text { or good } \\
\text { self-per- } \\
\text { ceived } \\
\text { health }\end{array}$ & $\begin{array}{l}\text { A subjective measure on how people } \\
\text { judge their health in general on a sca- } \\
\text { le from "very good" to "very bad" } \\
\text { (expressed as percentages of the popu- } \\
\text { lation). } \\
\text { For further analysis, only the answers } \\
\text { "very good" and "good" were taken } \\
\text { into consideration. }\end{array}$ & $\begin{array}{l}\text { Indicators of perceived general health } \\
\text { have been found to be a good predic- } \\
\text { tor of people's future health care use } \\
\text { and mortality (cf. Kaplan and Comach, } \\
\text { 1983; DeSalvo et al., 2006; Helmert, } \\
\text { 2003). While reasons for this relation- } \\
\text { ship are not yet completely clear to re- } \\
\text { searchers, a worse self-perception of he- } \\
\text { alth is linked with higher mortality. }\end{array}$ \\
\hline $\begin{array}{l}\text { Death due } \\
\text { to chronic } \\
\text { diseases per } \\
100,000 \\
\text { under } 65\end{array}$ & $\begin{array}{l}\text { The rate is calculated by dividing the } \\
\text { number of people under } 65 \text { dying due } \\
\text { to a chronic disease by the total popu- } \\
\text { lation under } 65 \text {. This value is then we- } \\
\text { ighted with the European Standard Po- } \\
\text { pulation. } \\
\text { Chronic diseases that this indicator inc- } \\
\text { ludes are: } \\
\text { malignant neoplasms, diabetes mellitus, } \\
\text { ischaemic heart diseases, cerebrovascu- } \\
\text { lar diseases, chronic lower respiratory } \\
\text { diseases and chronic liver diseases. }\end{array}$ & $\begin{array}{l}\text { Chronic diseases are not only handi- } \\
\text { caps to the sufferers, but as this indi- } \\
\text { cator measures it, they cause prematu- } \\
\text { re deaths, and so take away chances for } \\
\text { a longer life. }\end{array}$ \\
\hline
\end{tabular}




\begin{tabular}{|c|c|c|}
\hline Index & Description & Justification \\
\hline $\begin{array}{l}\text { Unmet me- } \\
\text { dical needs }\end{array}$ & $\begin{array}{l}\text { Self-reported unmet need for medical } \\
\text { care, as a percentage of the population } \\
\text { aged } 16 \text { and over. } \\
\text { The indicator measures the share of the } \\
\text { population aged } 16 \text { and over that repor- } \\
\text { ted unmet needs for medical care due } \\
\text { to one of the following reasons: "Finan- } \\
\text { cial reasons", "Waiting list" and "Too } \\
\text { far to travel". }\end{array}$ & $\begin{array}{l}\text { Self-reported unmet needs concern } \\
\text { a person's own assessment of whether } \\
\text { he or she needed medical examination } \\
\text { or treatment (dental care excluded), but } \\
\text { did not have it or did not seek it. This } \\
\text { indicator is derived from self-reported } \\
\text { data, so it is, to a certain extent, affec- } \\
\text { ted by the respondents' subjective per- } \\
\text { ception as well as by their social and } \\
\text { cultural background. }\end{array}$ \\
\hline $\begin{array}{l}\text { Hospital } \\
\text { beds } \\
\text { per } 100,000 \\
\text { inhabitants }\end{array}$ & $\begin{array}{l}\text { Hospital beds, as a number per } 100,000 \\
\text { inhabitants. } \\
\text { Total hospital beds are all hospital beds } \\
\text { which are regularly maintained and } \\
\text { staffed and immediately available for } \\
\text { the care of admitted patients; both oc- } \\
\text { cupied and unoccupied beds are cove- } \\
\text { red. }\end{array}$ & $\begin{array}{l}\text { This indicator provides information } \\
\text { on health care capacities, i.e., on the } \\
\text { maximum number of patients who can } \\
\text { be treated by hospitals, and better he- } \\
\text { althcare means better opportunities for } \\
\text { a long and healthy life. }\end{array}$ \\
\hline $\begin{array}{l}\text { Practicing } \\
\text { physicians } \\
\text { per } 100,000 \\
\text { inhabitants }\end{array}$ & $\begin{array}{l}\text { Practicing physicians, as a number per } \\
100,000 \text { inhabitants. }\end{array}$ & $\begin{array}{l}\text { When there are too few physicians who } \\
\text { can take care of patients, it becomes } \\
\text { a problem for the health care system, } \\
\text { and thus thorough, adequate and suffi- } \\
\text { cient treatment of patients is hindered. }\end{array}$ \\
\hline $\begin{array}{l}\text { Suicide } \\
\text { rate (per } \\
100,000)\end{array}$ & $\begin{array}{l}\text { Suicide rate, as a number per } 100,000 \\
\text { people. }\end{array}$ & $\begin{array}{l}\text { An act of committing suicide may } \\
\text { be seen as an eventual declaration } \\
\text { by a person who is unsatisfied with his/ } \\
\text { her life. }\end{array}$ \\
\hline $\begin{array}{l}\text { Air pol- } \\
\text { lution } \\
\text { exposure } \\
\text { (PM 10) }\end{array}$ & $\begin{array}{l}\text { Urban population exposure to air pol- } \\
\text { lution (PM 10), in micrograms per cu- } \\
\text { bic meter. } \\
\text { This indicator shows the population- } \\
\text {-weighted concentration of PM } 10 \\
\text { to which the urban population is poten- } \\
\text { tially exposed. Fine and coarse particu- } \\
\text { lates (PM 10) are those whose diameter } \\
\text { is less than } 10 \text { micrometers. }\end{array}$ & $\begin{array}{l}\text { Particulates can be carried deep into the } \\
\text { lungs where they can cause inflamma- } \\
\text { tion and a worsening of the condition } \\
\text { of people with heart and lung diseases. } \\
\text { The smaller the particles, the deeper } \\
\text { they travel into the lungs, with more } \\
\text { potential for harm. More air pollution } \\
\text { corresponds to more health problems, } \\
\text { and thus a lower quality of life, which } \\
\text { is why reducing the emission of pollu- } \\
\text { tants is an important issue regarding } \\
\text { human development. }\end{array}$ \\
\hline $\begin{array}{l}\text { Homicide } \\
\text { rate }\end{array}$ & $\begin{array}{l}\text { The death rate due to homicide, as num- } \\
\text { ber per } 100,000 \text { people. } \\
\text { It does not include deaths due to legal } \\
\text { interventions or war. }\end{array}$ & $\begin{array}{l}\text { This indicator offers some fairly valu- } \\
\text { able insight, as high homicide rates are } \\
\text { associated with low levels of human } \\
\text { development, which in turn fosters cri- } \\
\text { me (UNODC, 2011, p. 30). It might not } \\
\text { be strictly tied with Sen's human deve- } \\
\text { lopment concept; however, it remains } \\
\text { indirectly related to the level of deve- } \\
\text { lopment. }\end{array}$ \\
\hline
\end{tabular}




\begin{tabular}{|c|c|c|}
\hline Index & Description & Justification \\
\hline $\begin{array}{l}\text { At risk } \\
\text { of poverty } \\
\text { and social } \\
\text { exclusion }\end{array}$ & $\begin{array}{l}\text { People at risk of poverty or social exc- } \\
\text { lusion, as a percentage of the total po- } \\
\text { pulation. } \\
\text { This indicator corresponds to the sum } \\
\text { of persons who are: at risk of poverty } \\
\text { after social transfers, severely material- } \\
\text { ly deprived or living in households with } \\
\text { very low work intensity. People are co- } \\
\text { unted only once even if they are affec- } \\
\text { ted by more than one of these phenome- } \\
\text { na. People are considered to be at risk } \\
\text { of poverty after social transfers if they } \\
\text { have an equivalised disposable inco- } \\
\text { me below the risk-of-poverty threshold, } \\
\text { which is set at } 60 \% \text { of the national me- } \\
\text { dian equivalised disposable income. }\end{array}$ & $\begin{array}{l}\text { Severely materially deprived people } \\
\text { live in conditions severely constrained } \\
\text { by a lack of resources, they experience } \\
\text { at least } 4 \text { out of } 9 \text { following deprivations } \\
\text { items: cannot afford to pay rent or uti- } \\
\text { lity bills, keep their home adequately } \\
\text { warm, face unexpected expenses, eat } \\
\text { meat, fish or a protein equivalent eve- } \\
\text { ry second day, a week's holiday away } \\
\text { from home, a car, a washing machine, } \\
\text { a color TV, or a telephone. People living } \\
\text { in households with very low work in- } \\
\text { tensity are those aged } 0-59 \text { living in ho- } \\
\text { useholds where the adults (aged } 18-59 \text { ) } \\
\text { work } 20 \% \text { or less of their total work po- } \\
\text { tential during the past year. } \\
\text { Poverty is an important human deve- } \\
\text { lopment issue, as it is seen as a depriva- } \\
\text { tion of one or more capabilities. When } \\
\text { people are at risk of poverty, their capa- } \\
\text { bilities might be limited, and therefore } \\
\text { they cannot attain the freedom to lead } \\
\text { their lives as they would like to. }\end{array}$ \\
\hline $\begin{array}{l}\text { Poor dwel- } \\
\text { ling con- } \\
\text { ditions }\end{array}$ & $\begin{array}{l}\text { Population living in poor dwelling con- } \\
\text { ditions: with a leaking roof, damp wal- } \\
\text { ls, floors or foundations, or rot in win- } \\
\text { dow frames of the floor, as a percentage } \\
\text { of the population. }\end{array}$ & $\begin{array}{l}\text { Poor housing conditions are a form } \\
\text { of poverty, and, as such, they impede } \\
\text { the freedom of those who experience } \\
\text { them, which is why the factor is consi- } \\
\text { dered here while discussing human de- } \\
\text { velopment. }\end{array}$ \\
\hline $\begin{array}{l}\text { Overcrow- } \\
\text { ding rate }\end{array}$ & $\begin{array}{l}\text { Overcrowding rate, as a percentage } \\
\text { of the population. } \\
\text { A person is considered to be living } \\
\text { in an overcrowded household if the ho- } \\
\text { use does not have at least one room for } \\
\text { the entire household as well as a room } \\
\text { for a couple, for each single person } \\
\text { above } 18 \text {, for a pair of teenagers (from } \\
12 \text { to } 17 \text { years old) of the same sex, for } \\
\text { each teenager of different sex, and for } \\
\text { a pair of children (under } 12 \text { years old). }\end{array}$ & $\begin{array}{l}\text { Overcrowding has an impact on quality } \\
\text { of life, especially on health, due to in- } \\
\text { creased physical contact, lack of sleep, } \\
\text { lack of privacy, not being able to take } \\
\text { adequate care of sick household mem- } \\
\text { bers, and poor hygiene practices (Gray, } \\
2001, \text { p. 5). }\end{array}$ \\
\hline
\end{tabular}




\begin{tabular}{|c|c|c|}
\hline Index & Description & Justification \\
\hline $\begin{array}{l}\text { Share of } \\
\text { renewable } \\
\text { energy }\end{array}$ & $\begin{array}{l}\text { Share of renewable energy, as a per- } \\
\text { centage. } \\
\text { This indicator measures the share of re- } \\
\text { newable energy consumption in gross } \\
\text { final energy consumption according } \\
\text { to the Renewable Energy Directive. The } \\
\text { gross final energy consumption is the } \\
\text { energy used by end-consumers (final } \\
\text { energy consumption) plus grid losses } \\
\text { and self-consumption of power plants. }\end{array}$ & $\begin{array}{l}\text { Sustainable energy is central to eco- } \\
\text { nomic development, social progress, } \\
\text { and environmental sustainability, and } \\
\text { it is one of the UN Sustainable Deve- } \\
\text { lopment Goals. Lowering consumption } \\
\text { of energy from fossil fuels and incre- } \\
\text { asing the share of renewable energy } \\
\text { is not only important from the per- } \\
\text { spective of people's health, which can } \\
\text { be worsened by smog and air pollu- } \\
\text { tion that are results of burning coal and } \\
\text { other fossil fuels. It is also essential } \\
\text { in light of dealing with global warming, } \\
\text { which is a problem that is consistently } \\
\text { becoming more pressing. }\end{array}$ \\
\hline $\begin{array}{l}\text { Young pe- } \\
\text { ople neither } \\
\text { in employ- } \\
\text { ment nor } \\
\text { in education } \\
\text { and training } \\
\text { (NEET) }\end{array}$ & $\begin{array}{l}\text { NEET rate, as a percentage of the popu- } \\
\text { lation aged } 15 \text { to } 29 \text {. This indicator me- } \\
\text { asures the share of the population aged } \\
15 \text { to } 29 \text { who are not employed and not } \\
\text { involved in education or training. }\end{array}$ & $\begin{array}{l}\text { Young people experience some difficul- } \\
\text { ties during the transition to adult life, } \\
\text { but it becomes an issue when they en- } \\
\text { counter extended periods of exclusion } \\
\text { from work and education. Such long } \\
\text { periods can result in the intensification } \\
\text { of socially unwanted behavior, such } \\
\text { as criminal activity, and in problems } \\
\text { with physical as well as mental health. } \\
\text { This, in turn, negatively influences pe- } \\
\text { ople's capabilities and abilities to make } \\
\text { life choices freely. }\end{array}$ \\
\hline $\begin{array}{l}\text { Adult lear- } \\
\text { ning }\end{array}$ & $\begin{array}{l}\text { Adult participation in learning, as a per- } \\
\text { centage of the population aged } 25 \text { to } 64 \text {. } \\
\text { Adult learning covers formal and non- } \\
\text {-formal learning activities, both general } \\
\text { and vocational, undertaken by adults } \\
\text { after leaving initial education and tra- } \\
\text { ining. }\end{array}$ & $\begin{array}{l}\text { In times of rapid socio-economic and } \\
\text { technological changes, people that } \\
\text { do not extend their competencies accor- } \\
\text { dingly might find it difficult to rema- } \\
\text { in employed. Furthermore, as Europe } \\
\text { is challenged with an aging society, li- } \\
\text { felong learning might be an opportunity } \\
\text { to keep these older people in good men- } \\
\text { tal shape, as exercising the brain may } \\
\text { help to preserve it in good condition, } \\
\text { thus allowing for a longer healthy life } \\
\text { (Grady, 2012). }\end{array}$ \\
\hline
\end{tabular}




\begin{tabular}{|l|l|l|}
\hline \multicolumn{1}{|c|}{ Index } & \multicolumn{1}{|c|}{ Description } & \multicolumn{1}{c|}{ Justification } \\
\hline $\begin{array}{l}\text { Households } \\
\text { with inter- } \\
\text { net access }\end{array}$ & $\begin{array}{l}\text { Households with internet access, } \\
\text { as a percentage of population. } \\
\text { This indicator measures the share of ho- } \\
\text { useholds that have internet access; } \\
\text { the data are collected through annual } \\
\text { surveys. }\end{array}$ & $\begin{array}{l}\text { Technology has a huge impact on eve- } \\
\text { ry aspect of life in modern times, and } \\
\text { having access to these technologies } \\
\text { would facilitate human development } \\
\text { (UNDP 2015, p. 10). It was estima- } \\
\text { ted that if internet access was the same } \\
\text { in developing countries as it is in de- } \\
\text { veloped ones, long-time productivity } \\
\text { could increase by 25\% (UNDP 2015, } \\
\text { p. 10). Internet access facilitates com- } \\
\text { munication and extends opportunities, } \\
\text { as well as increasing people's potential } \\
\text { and enabling them to further make use } \\
\text { of their freedoms. }\end{array}$ \\
\hline $\begin{array}{l}\text { Real GDP } \\
\text { per capita }\end{array}$ & $\begin{array}{l}\text { Real GDP per capita, chain-linked volu- } \\
\text { mes (2010), euro per capita. The indica- } \\
\text { tor is calculated as the ratio of real GDP } \\
\text { to the average population of a specific } \\
\text { year. GDP measures the value of total } \\
\text { final output of goods and services pro- } \\
\text { duced by an economy within a certa- } \\
\text { in period of time, including goods and } \\
\text { services that have markets (or which } \\
\text { could have markets) and products which } \\
\text { are produced by general government } \\
\text { and non-profit institutions. }\end{array}$ & $\begin{array}{l}\text { measure of human development } \\
\text { nor a measure of economic welfare, } \\
\text { it still is a representation of some } \\
\text { capabilities that people have in a certain } \\
\text { country, and it may be used as a proxy } \\
\text { of development in a country's living } \\
\text { standards. }\end{array}$ \\
\hline
\end{tabular}

Source: own elaboration

The first seven indicators are related to health care, indicators from 8 to 13 pertain to the quality of the natural and social environment, the next three indices are connected with education, and the last one is real GDP per capita.

The chosen five countries were assigned ranks from 1 to 5 according to the values of the indices, separately, for the years 2005, 2010, and 2015. These ranks were then summed up for each year. The country with the lowest rank is the one that performed best out of the group, as it occupies the highest positions in the ranking the most often; similarly, the country with the highest number performs the worst. The sum of ranks ranges from 17 to 85 . For comparison purposes, the averages of all current 28 European Union countries were also included in the table. The results are shown in Tables 3 to 5 below. 


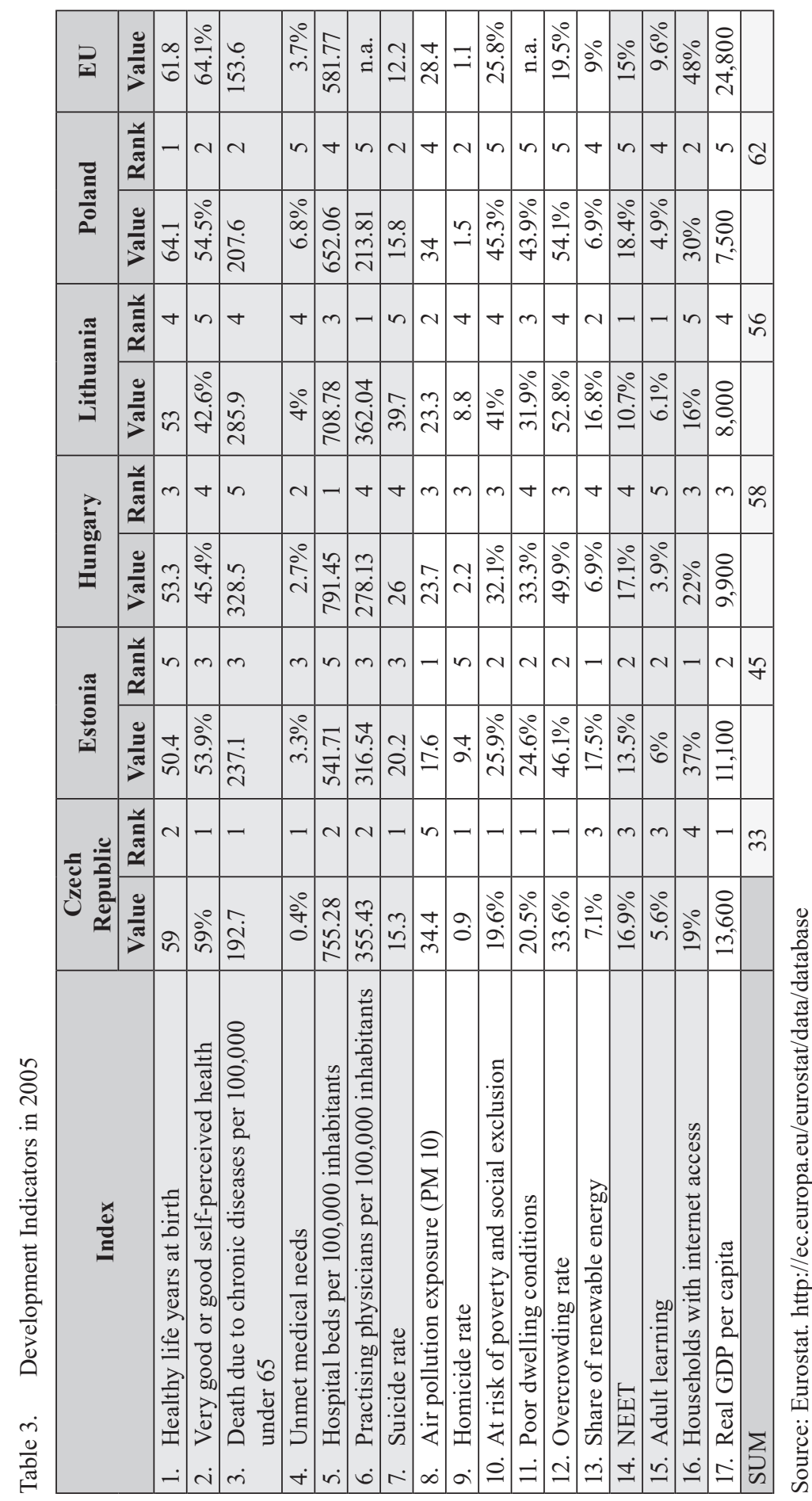




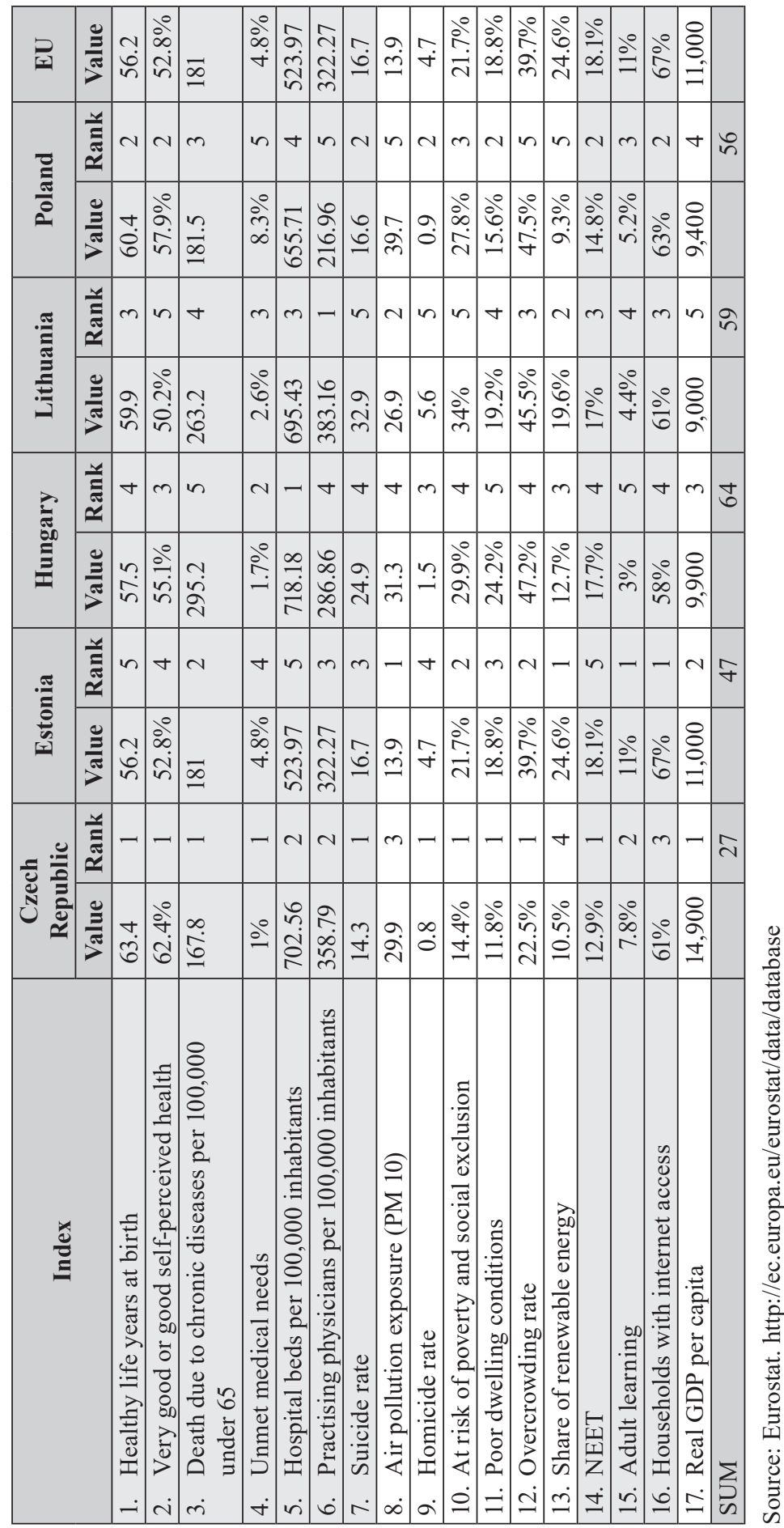




\begin{tabular}{|c|c|c|c|c|c|c|c|c|c|c|c|c|c|c|c|c|c|c|}
\hline 도 & 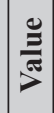 & 6 & 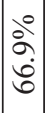 & 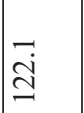 & 仓ें & $\begin{array}{l}0 \\
\ddot{0} \\
\dot{m} \\
\tilde{n}\end{array}$ & $\stackrel{\stackrel{\oplus}{\oplus}}{=}$ & $\stackrel{\overrightarrow{0}}{=}$ & $\begin{array}{l}\infty \\
i \\
i\end{array}$ & $\begin{array}{l}\hat{b} \\
\dot{0}\end{array}$ & $\begin{array}{c}00 \\
\infty \\
\grave{\lambda}\end{array}$ & $\begin{array}{l}\text { ஸें } \\
\text { ஸे } \\
\end{array}$ & $\mid \begin{array}{l}0 \\
\stackrel{0}{0} \\
-\end{array}$ & \begin{tabular}{l|l}
$\stackrel{0}{\circ}$ \\
$\stackrel{2}{0}$
\end{tabular} & 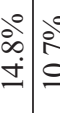 & 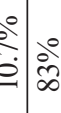 & $\begin{array}{ll}0 & 8 \\
0 & 0 \\
0 \\
0 \\
0 \\
0\end{array}$ & \\
\hline \multirow{2}{*}{ } & 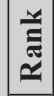 & $v$ & $\sim$ & $m$ & $\nabla$ & $m$ & $n$ & $N$ & in & -1 & $\sim \sigma^{\circ}$ & $\sim$ & $\ln \mid$ & $n \mid c$ & $m \mid$ in & $n \mid m$ & $n$ & in \\
\hline & 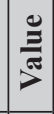 & $\frac{-}{6}$ & $\mid \begin{array}{l}\stackrel{0}{a} \\
\hat{i} \\
\text { | }\end{array}$ & $\stackrel{0}{0}$ & 仓ें & 今े & $\begin{array}{l}\vec{\infty} \\
i \\
\tilde{\sim}\end{array}$ & $\stackrel{f}{\stackrel{f}{ \pm}}$ & $\vec{m}$ & $\begin{array}{l}\infty \\
\stackrel{0}{0}\end{array}$ & $\mid \begin{array}{c}0 \\
\dot{+} \\
\dot{v} \\
\vec{v}\end{array}$ & 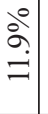 & $\mid \begin{array}{c}\stackrel{0}{\circ} \\
\dot{\gamma} \\
\dot{\gamma}\end{array}$ & 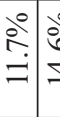 & 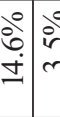 & co & 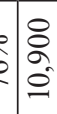 & \\
\hline \multirow{2}{*}{ 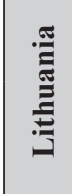 } & 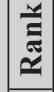 & $\nabla$ & in & 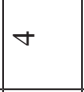 & $m$ & $N$ & -1 & in & $N \mid$ & $n$ & $\ln \mid$ & $\nabla$ & $m$ & $N-$ & $-\nabla$ & $\nabla \mid \nabla$ & $+m$ & in \\
\hline & 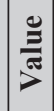 & 㔯 & $\begin{array}{l}\stackrel{0}{ } \\
\infty \\
\stackrel{\gamma}{f}\end{array}$ & $\frac{n}{\curvearrowright}$ & $\mid \begin{array}{l}\stackrel{0}{\grave{i}} \\
\text { ते }\end{array}$ & $\begin{array}{l}\overline{6} \\
\stackrel{0}{0} \\
\text { oे }\end{array}$ & $\begin{array}{c}\widetilde{\sigma} \\
\tilde{\partial} \\
\tilde{\gamma}\end{array}$ & ㄹ. & $\stackrel{\vec{i}}{\dot{\vec{v}}}$ & $\underset{\forall}{\exists}$ & $\begin{array}{l}\stackrel{0}{2} \\
\text { ஸे }\end{array}$ & $\stackrel{\circ}{\stackrel{\Xi}{ }}$ & 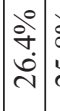 & 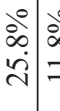 & 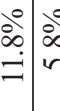 & \begin{tabular}{c|c}
0 \\
$\infty$ \\
$\dot{0}$ \\
$\dot{0}$
\end{tabular} & $\begin{array}{l}0 \\
0 \\
0 \\
0 \\
0 \\
0\end{array}$ & \\
\hline \multirow{2}{*}{ 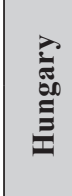 } & 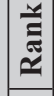 & $m$ & $m$ & in & $\sim \mid$ & - & $\nabla$ & $\nabla$ & $\nabla$ & $m$ & +14 & $n$ & +1 & $\nabla \mid$ & $+\mid c$ & $m m$ & $r+$ & 8 \\
\hline & 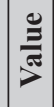 & ì & $\mid \begin{array}{l}0 \\
\dot{y} \\
\dot{0} \\
n\end{array}$ & $\begin{array}{l}\hat{n} \\
\tilde{n} \\
\tilde{n}\end{array}$ & $\mid \begin{array}{l}0 \\
\dot{b} \\
i\end{array}$ & ने & $\begin{array}{l}\mathbb{N} \\
\stackrel{2}{a} \\
\stackrel{\rho}{\rho}\end{array}$ & $\begin{array}{l}\hat{\alpha} \\
\infty \\
-1\end{array}$ & $\begin{array}{l}\stackrel{a}{b} \\
\text { iे }\end{array}$ & $\stackrel{\infty}{\sim}$ & 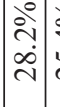 & 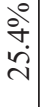 & $\begin{array}{l}\stackrel{0}{0} \\
\dot{\dot{\gamma}}\end{array}$ & 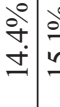 & $\frac{\circ}{\circ}$ & है & $\begin{array}{l}0 \\
0 \\
0 \\
\end{array}$ & \\
\hline \multirow{2}{*}{ 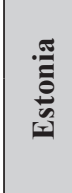 } & 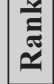 & in & $\nabla$ & $N$ & in & in & $m$ & $m$ & - & $\nabla$ & $m \mid c$ & $m$ & -1 & -10 & $N-$ & $-1-$ & $-N$ & \& \\
\hline & 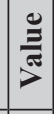 & in & 悹 & 品 & 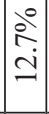 & 余 & 守 & $\begin{array}{l} \pm \\
\stackrel{2}{2} \\
-1\end{array}$ & $\cong$ & \begin{tabular}{c}
\multirow{J}{0}{} \\
$\dot{r}$ \\
\end{tabular} & 宅 & $\begin{array}{l}\stackrel{0}{\circ} \\
\stackrel{0}{0} \\
\stackrel{2}{二}\end{array}$ & $\mid \begin{array}{c}0 \\
\dot{v} \\
\dot{0}\end{array}$ & 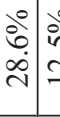 & 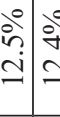 & 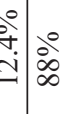 & \begin{tabular}{l|l}
0 \\
0 \\
0 \\
0 \\
0 \\
0
\end{tabular} & \\
\hline \multirow{2}{*}{ 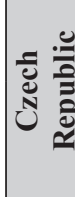 } & 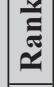 & - & -1 & - & -1 & t & $\sim$ & -1 & $m$ & $\sim$ & -1 & -1 & $N$ & $m-$ & -0 & $N \mid N$ & $\mathrm{v}-$ & خे \\
\hline & $\frac{\mathscr{O}}{\frac{\Xi}{\pi}}$ & $=$ & लें & $\stackrel{\Xi}{\dot{\Xi}}$ & $\begin{array}{c}0 \\
\infty \\
\dot{0} \\
\dot{0}\end{array}$ & \begin{tabular}{l}
$\vec{n}$ \\
$\infty$ \\
\multirow{0}{0}{}
\end{tabular} & 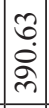 & 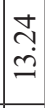 & $\stackrel{m}{\stackrel{m}{\sim}}$ & $\begin{array}{l} \pm \\
\infty \\
0\end{array}$ & 过 & $\begin{array}{l}\text { ڤें } \\
\text { के }\end{array}$ & $\mid \begin{array}{c}\stackrel{0}{0} \\
0 \\
-\infty\end{array}$ & i̊ำ & $\begin{array}{lll}0 \\
\infty & 0 \\
\vdots & \infty \\
& \infty\end{array}$ & $\begin{array}{c}\circ \\
\vdots \\
\infty\end{array}$ & 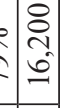 & \\
\hline \multicolumn{2}{|c|}{ 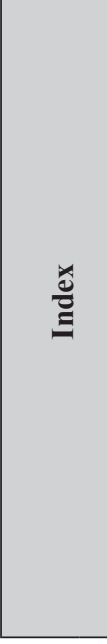 } & 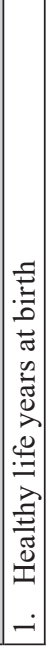 & 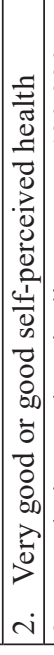 & 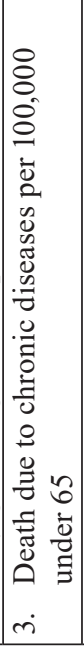 & 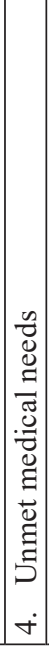 & 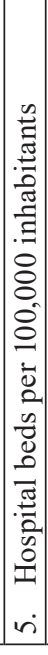 & 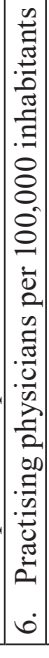 & 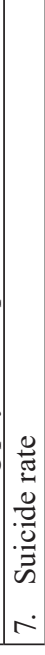 & 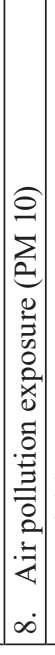 & 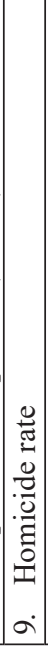 & 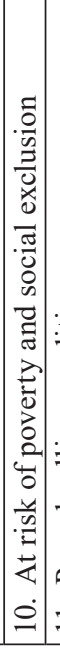 & 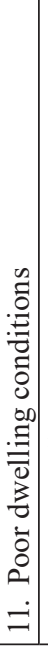 & 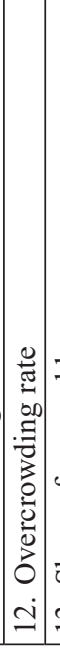 & 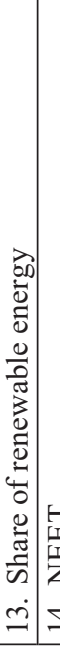 & 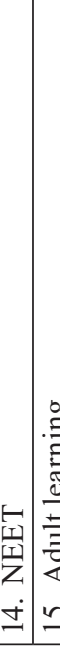 & 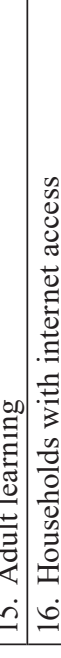 & 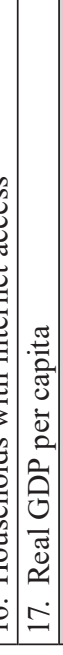 & $\mid$ \\
\hline
\end{tabular}


In general, the Czech Republic performed the best, with the lowest sum of ranks in all three years; Estonia is the second-best and similarly occupies second place in all three years. Regarding the remaining three countries, in 2005, third place was held by Lithuania, fourth by Hungary, with Poland in last place. In 2010, Poland jumped to third place, with Lithuania fourth and Hungary last. In 2015, Poland and Lithuania obtained the same sum of ranks, thus both being in third place, while Hungary remained the worst performer out of the five.

The differences between the countries' sums are worth noting. In 2005 and 2010, Estonia was behind the Czech Republic by 12 points, while in 2015 this difference grew to 18 points. Estonia surpassed the third country by 11 points in 2005,16 points in 2010 , and 11 points in 2015. The differences between the three lowest performing countries were not very significant, varying from 3 to 6 points. The reason for this might be that for Hungary, Lithuania and Poland, even if they showed improving results, the pace of these improvements might have been similar to those of the Czech Republic and Estonia; thus, the three countries were not able to achieve results so significantly different to surpass the two leaders. It cannot be said that these three lowest scoring countries never held the first position in any category; however, it occurred more infrequently than in the case of the Czech Republic or Estonia.

\section{Public opinion surveys as a source of human development data}

Another attempt to examine human development in certain countries can be made with public opinion surveys. Such surveys for the chosen five countries were obtained from Eurobarometer and the European Quality of Life Survey (QLS) data. Three questions were chosen from the data available dealing with overall happiness, satisfaction with life, and satisfaction with national democracy. ${ }^{1}$ The last question pertains to the subjective feelings about the state of democracy in the citizen's country. This aspect was not covered in the HDI, and because of that, it was not included in the set of indicators to which the HDI has been compared in the previous section. However, democracy is needed for freedom, and this relationship was also strongly accentuated by Sen.

The first question taken from the QLS was: Taking all things together, how happy would you say you are? The answers were on a scale from 1 to 10 , and the results are presented in Table 6.

In 2007, the mean answer to this question out of the five chosen countries was the highest for the Czech Republic: 7.5, which was also the European Union average. In 2011 the results for all the countries fell: the best was for Poland, with 7.3. The second highest was the Czech Republic's 7.1, next Lithuania with 7.0, followed by Hungary's 6.9 and Estonia's 6.8. The EU average also fell, to 7.4. This fall in citizens' happiness might have

\footnotetext{
${ }^{1}$ In the case of the of Eurobarometer, the results of the survey questions were taken for 2005, 2010, and 2015, to be comparable with previous data, while for the QLS the data were taken for 2007, 2011, and 2016, due to the fact that this survey is conducted only every 5 years.
} 
been the result of the 2008 crisis and its aftermath, as in the 2016 survey, the mean happiness rose for most countries. Poland remained on top with the highest score of 7.5, and next was Estonia with an increase to 7.2.

Table 6. The answers to the question: Taking all things together, how happy would you say you are? (years 2007, 2011, 2016)

\begin{tabular}{|l|c|c|c|}
\cline { 2 - 4 } \multicolumn{1}{c|}{} & $\mathbf{2 0 0 7}$ & $\mathbf{2 0 1 1}$ & $\mathbf{2 0 1 6}$ \\
\hline Czech Republic & 7.5 & 7.1 & 6.8 \\
\hline Estonia & 7.4 & 6.8 & 7.2 \\
\hline Hungary & 7.0 & 6.9 & 7.0 \\
\hline Lithuania & 7.3 & 7.0 & 7.0 \\
\hline Poland & 7.4 & 7.3 & 7.5 \\
\hline
\end{tabular}

Source: European Quality of Life Survey 2007, 2011, 2016. https://www.eurofound.europa.eu/

The second question was taken from the Eurobarometer, and it was: On the whole, are you very satisfied, fairly satisfied, not very satisfied or not at all satisfied with the life you lead? The results are shown in Table 7.

Table 7. The answers to the question: On the whole, are you very satisfied, fairly satisfied, not very satisfied or not at all satisfied with the life you lead? (years 2005, 2010, 2015; in \%)

\begin{tabular}{|c|c|c|c|c|c|c|}
\hline & \multirow{3}{*}{$\begin{array}{c}\begin{array}{c}\text { Very } \\
\text { satisfied }\end{array} \\
13\end{array}$} & \multirow{3}{*}{$\begin{array}{c}\text { Fairly } \\
\text { satisfied } \\
70\end{array}$} & \multirow{3}{*}{$\begin{array}{c}\begin{array}{c}\text { Not very } \\
\text { satisfied }\end{array} \\
15\end{array}$} & \multirow{3}{*}{$\begin{array}{c}\begin{array}{c}\text { Not at all } \\
\text { satisfied }\end{array} \\
2\end{array}$} & \multirow{3}{*}{$\begin{array}{c}\text { Don't know } \\
0\end{array}$} \\
\hline & & & & & & \\
\hline \multirow{3}{*}{ Czech Republic } & 2005 & & & & & \\
\hline & 2010 & 12 & 66 & 19 & 3 & 0 \\
\hline & 2015 & 17 & 66 & 14 & 2 & 0 \\
\hline \multirow{3}{*}{ Estonia } & 2005 & 7 & 61 & 27 & 5 & 0 \\
\hline & 2010 & 9 & 65 & 23 & 4 & 0 \\
\hline & 2015 & 11 & 68 & 19 & 2 & 0 \\
\hline \multirow{3}{*}{ Hungary } & 2005 & 10 & 44 & 34 & 12 & 0 \\
\hline & 2010 & 5 & 45 & 35 & 15 & 0 \\
\hline & 2015 & 9 & 55 & 27 & 21 & 0 \\
\hline \multirow{3}{*}{ Lithuania } & 2005 & 9 & 44 & 34 & 11 & 1 \\
\hline & 2010 & 10 & 40 & 35 & 15 & 0 \\
\hline & 2015 & 17 & 57 & 21 & 5 & 0 \\
\hline \multirow{3}{*}{ Poland } & 2005 & 14 & 55 & 24 & 6 & 1 \\
\hline & 2010 & 15 & 65 & 15 & 4 & 2 \\
\hline & 2015 & 13 & 67 & 15 & 3 & 2 \\
\hline
\end{tabular}

Source: Eurobarometer. http://ec.europa.eu/commfrontoffice/publicopinion/index.cfm/Chart/index

In 2005, in all the countries, the most frequent answer was "fairly satisfied"; in the Czech Republic, it was 70\% of all answers, in Estonia 61\%, in Poland 55\%, while in Hungary and Lithuania it was $44 \%$, with the EU average being $60 \%$. However, the second most frequent answer was "not very satisfied"; in Hungary and Lithuania this answer was $34 \%$ of all answers, in Estonia 27\%, in Poland 24\%, and the Czech Republic 15\%, while 
the EU average for this answer was $15 \% .14 \%$ of respondents in Poland answered "very satisfied", in the Czech Republic 13\%, in Hungary 10\%, in Lithuania 9\%, and in Estonia $7 \%$, while the EU average for this question was quite higher $-21 \%$. The answer "not at all satisfied" was most often indicated in Hungary - 12\%, and Lithuania - $11 \%$, while in Poland it was 6\%, in Estonia 5\%, and in the Czech Republic, 2\%; the EU average in this case was $4 \%$.

In 2010, the tendency was similar. The most frequent answer was "fairly satisfied", in the Czech Republic, getting 66\% of all answers, in Estonia and Poland 65\%, in Hungary $45 \%$, and in Lithuania $40 \%$, while the EU average was $57 \%$. The next most frequent answer was "not very satisfied": in Hungary and Lithuania it was $35 \%$ of all answers, in Estonia 23\%, in the Czech Republic 19\%, and in Poland 15\%, and for the whole EU it was $16 \%$. The answer "very satisfied" was most frequent in Poland $-15 \%$, in the Czech Republic $12 \%$, in Lithuania 10\%, in Estonia 9\%, and in Hungary only 5\%, while for the EU it was $21 \% .15 \%$ of Hungarians and Lithuanians answered "not at all satisfied", as did $4 \%$ of Estonians and Poles, 3\% of Czechs, and 6\% of all European Union citizens.

In 2015, the frequency of the answer "not very satisfied" fell in favor of "very satisfied". "Not very satisfied" was given by $27 \%$ of respondents in Hungary, $21 \%$ in Lithuania, 19\% in Estonia, 15\% in Poland, 14\% in the Czech Republic, and 15\% in the EU. "Very satisfied" was indicated by $17 \%$ of Czechs and Lithuanians, $13 \%$ of Poles, $11 \%$ of Estonians and $9 \%$ of Hungarians, as well as $23 \%$ of all EU citizens. "Fairly satisfied" remained the most often answer to the asked question: $68 \%$ for Estonia, $67 \%$ for Poland, $66 \%$ for the Czech Republic, 57\% for Lithuania and the EU, and 55\% for Hungary. The frequency of "not at all satisfied" people fell for Hungary and Lithuania, to $8 \%$ and 5\%, respectively. It was 3\% for Poland, and $2 \%$ for the Czech Republic and Estonia.

The third question was taken from the Eurobarometer: On the whole, are you very satisfied, fairly satisfied, not very satisfied or not at all satisfied with the way democracy works in (your country)? The results are shown in Table 8.

In 2005, the majority of answers were either "fairly satisfied" or "not very satisfied". There was, however, a difference between the distribution of these answers, as in the cases of the Czech Republic and Estonia, the shares of those two responses were almost equal. In the case of the other three countries, about twice as many respondents declared that they were "not very satisfied" than "fairly satisfied".

In 2010, the situation looked quite similar in all the countries but Poland. In Poland, the share of people "fairly satisfied" grew significantly (from 27 to 51 percent), while those who were "not very satisfied" shrank (from 41 to 31 percent).

In 2015, the results were similar to those from 2010. There were two tendencies worth noticing though. In Hungary, the share of respondents "not very satisfied" declined, accompanied by the growth of those who were "not at all satisfied". In Lithuania, there was an outflow of those declaring a lack of satisfaction with the way democracy functioned, from $28 \%$ to $16 \%$, while the share of people expressing their satisfaction grew from $16 \%$ to $32 \%$. 
Table 8. On the whole, are you very satisfied, fairly satisfied, not very satisfied or not at all satisfied with the way democracy works in (your country)? (years 2005, 2010, 2015; in \%)

\begin{tabular}{|l|c|c|c|c|c|c|}
\cline { 3 - 7 } \multicolumn{2}{c|}{} & $\begin{array}{c}\text { Very } \\
\text { satisfied }\end{array}$ & $\begin{array}{c}\text { Fairly } \\
\text { satisfied }\end{array}$ & $\begin{array}{c}\text { Not very } \\
\text { satisfied }\end{array}$ & $\begin{array}{c}\text { Not at all } \\
\text { satisfied }\end{array}$ & Don't know \\
\hline \multirow{3}{*}{ Czech Republic } & 2005 & 3 & 45 & 37 & 14 & 2 \\
\cline { 2 - 8 } & 2010 & 3 & 42 & 40 & 14 & 1 \\
\cline { 2 - 8 } & 2015 & 6 & 46 & 36 & 10 & 2 \\
\hline \multirow{3}{*}{ Estonia } & 2005 & 3 & 41 & 40 & 11 & 5 \\
\cline { 2 - 8 } & 2010 & 3 & 42 & 41 & 11 & 3 \\
\cline { 2 - 8 } & 2015 & 2 & 45 & 38 & 9 & 6 \\
\hline \multirow{3}{*}{ Hungary } & 2005 & 2 & 25 & 48 & 24 & 2 \\
\cline { 2 - 8 } & 2010 & 3 & 33 & 46 & 18 & 1 \\
\cline { 2 - 8 } & 2015 & 3 & 34 & 35 & 26 & 1 \\
\hline \multirow{3}{*}{ Poland } & 2005 & 4 & 19 & 50 & 22 & 4 \\
\cline { 2 - 8 } & 2010 & 1 & 16 & 51 & 28 & 4 \\
\cline { 2 - 8 } & 2015 & 1 & 32 & 46 & 16 & 4 \\
\cline { 2 - 8 } & 2005 & 2 & 27 & 41 & 26 & 6 \\
\cline { 2 - 8 } & 2010 & 4 & 51 & 31 & 8 & 70 \\
\hline
\end{tabular}

Source: Eurobarometer. http://ec.europa.eu/commfrontoffice/publicopinion/index.cfm/Chart/index

\section{A comparison of the measures of human development}

In order to compare the results of the HDI rankings and data gathered from Eurostat, ranks were given to the positions of each country for those two ways of expressing the level of development for the years 2005, 2010 and 2015. The countries that performed the best out of the five were given the rank of 1, and the worst were given the rank of 5 . These results are presented in Table 9.

Table 9. Position of chosen countries according to the HDI and Eurostat human development indicators for the years 2005, 2010 and 2015.

\begin{tabular}{|l|c|c|c|c|c|c|}
\hline \multirow{2}{*}{} & \multicolumn{2}{|c|}{2005} & \multicolumn{2}{c|}{$\mathbf{2 0 1 0}$} & \multicolumn{2}{c|}{2015} \\
\cline { 2 - 7 } & HDI & Eurostat & HDI & Eurostat & HDI & Eurostat \\
\hline Czech Republic & 1 & 1 & 1 & 1 & 1 & 1 \\
\hline Estonia & 5 & 2 & 2 & 2 & 2 & 2 \\
\hline Hungary & 2 & 4 & 3 & 5 & 5 & 4 \\
\hline Lithuania & 4 & 3 & 5 & 4 & 4 & 3 \\
\hline Poland & 3 & 5 & 4 & 3 & 3 & 3 \\
\hline
\end{tabular}

Source: Own elaboration. 
In both of the approaches, in all three years, the Czech Republic remains the leader, consistently occupying first place. The case is similar with Estonia, which was ranked second in both 2010 and 2015. However, in 2005 there was quite a big difference between Estonia's position in the HDI ranking, where it was the last out of the five, and the one based on Eurostat data, where it was second. Looking closer, in the remaining three countries there were discrepancies between the HDI ranking and the Eurostat ranks. In the case of Hungary, in 2005 and 2010, the HDI ranked the country's performance better than it was according to the Eurostat data by two positions: in 2005 it was second and in 2010 third in the HDI, and fourth and fifth respectively in Eurostat ranks. In 2015, this changed and the HDI ranked Hungary one position lower than for Eurostat, fifth in HDI and fourth in Eurostat ranks. For Lithuania, the situation was similar as for Hungary in 2015. In all three years, Lithuania performed better according to Eurostat data than in the HDI. In 2005, the country was fourth in the HDI, and third in Eurostat, in 2010 it was fifth and fourth, respectively, and in 2015 fourth and third again. The situation of Poland was mixed. In 2005, it ranked better according to HDI (third position) than to Eurostat data (fifth position); however, in 2010 this reversed, and Poland was fourth in the HDI and third in the Eurostat ranks, while in 2015 it occupied third place in both the HDI and Eurostat data.

Regarding the performance of the five chosen countries according to public opinion surveys, it would be an oversimplification to give ranks to countries depending on the answers expressed by the respondents, and thus no ranking shall be made in this case.

As for the first question of the surveys, judging happiness, in 2007, the Czech Republic was the country with the highest mean score, and it was the one with the highest 2005 HDI and Eurostat rank out of the five. In the 2011 survey, this country fell to second place and in 2016 to last place, clearly a discrepancy from the HDI and Eurostat results, in which The Czech Republic remains the country with the highest human development from the group. Estonia in 2007 was second-best alongside Poland, which was the same in the case of the 2005 Eurostat ranks, but in HDI it was placed last. In 2011, it fell to the "least happy with life" position, while according to Eurostat in 2010 and the HDI, it ranked second, and in the 2016 survey, it came second, just like in the two other 2015 rankings. Hungary did not perform very well in this survey, achieving the lowest score in 2007, while in 2005 it was second in HDI and fourth in Eurostat ranks. In the 2011 survey, it was fourth, while in 2010 HDI it was third and in Eurostat fifth. In the 2016 survey, it came third alongside Lithuania, while in 2015 HDI ranking it fell to the last position and in Eurostat to the fourth. In the case of Lithuania, in 2007 it performed as in the 2005 HDI ranking, coming fourth, while in the Eurostat data it was third. In the 2011 survey, the state was third happiest; however, in both the 2010 HDI and Eurostat ranks it performed worse, in fifth and fourth position, respectively. In the 2016 survey, it was third, just as in the 2015 Eurostat rank, while in the HDI it came fourth. Last but not least, in the 2007 survey, Poland scored the second-best result with Estonia, while in the 2005 HDI ranking it was third and in Eurostat data it was last. In both the 2011 and 2016 happiness surveys, it came first, quite a difference from the ranks in the two other indicators. In 2010, it was fourth in the HDI and third in the Eurostat ranks, and in 2015 it was third in both rankings.

In both the HDI and Eurostat data throughout the years, The Czech Republic is pictured as the country with the highest human development out of the group. Regarding the data from the questionnaire about satisfaction with life, this image is upheld. In 2005 , 
$13 \%$ of Czechs were "very satisfied" with their lives, in 2010 this share fell slightly to $12 \%$, and in 2015 it grew to $17 \%$. At the same time, the share of Czechs "fairly satisfied" was around $70 \%$, and those "not very satisfied" was $15 \%$ in $2005,19 \%$ in 2010 , and then $14 \%$ in 2015. This means that in all the years considered, around $80 \%$ of Czechs were at least fairly satisfied with their lives, which is a good result. As for the data regarding the satisfaction with national democracy, things are slightly less optimistic. The share of Czechs who had some dissatisfaction with the democracy in their country was quite high throughout the years. In 2005 and 2010, 14\% were "not at all satisfied" with he state of democracy, and in 2015 this fell to $10 \%$. However, the share of those who were "not very satisfied" was $37 \%$ in $2005,40 \%$ in 2010 , and $36 \%$ in 2015 . Each year, around half of Czechs were, to some extent, not satisfied with the democracy in their state. Only $45 \%$ in 2005 , $42 \%$ in 2010, and 46\% in 2015 were "fairly satisfied" with it.

Apart from the HDI ranking in 2005, Estonia steadily performed quite well as the second-best country from the chosen five in both the HDI and Eurostat ranks. Regarding the survey on satisfaction with life, it managed mostly to maintain these good results. The share of Estonians "very satisfied" with life in 2005 was 13\%, in 2010 it fell slightly to $12 \%$, and in 2015 it rose to $17 \%$. Many Estonians were also "fairly satisfied" with their lives, and this share increased throughout the years: $61 \%$ in 2005 , then $65 \%$ in 2010 , and $68 \%$ in 2015 . The share of those "not very satisfied" was slightly higher than in the Czech Republic; however, it decreased over time, from 27\% in 2005, to 23\% in 2010 and $19 \%$ in 2015 . Regarding the satisfaction with national democracy, the situation is worse. There were fewer Estonians "not at all satisfied" than Czechs, only around 10\% each year. The share of Estonians that are "not very satisfied" and "fairly satisfied" both remained around $40 \%$ in all the years.

Hungary's situation remains mixed when comparing its ranks in the HDI and Eurostat. Regarding the survey on satisfaction with life, the country's results improve with time. Although the share of Hungarians who were "very satisfied" was unstable, going from $10 \%$ in 2005 , to $5 \%$ in 2010 , and $9 \%$ in 2015 , the share of those "fairly satisfied" increased (from $44 \%$ to $55 \%$ in ten years). The share of those who were "not very satisfied" decreased, from $34 \%$ in 2005 to $27 \%$ in 2015 . Unfortunately, the results of the questionnaire concerning the state of democracy in the country were worse. The share of those who are "not at all satisfied" was as high as $24 \%$ in $2005,18 \%$ in 2010 , and again back to $26 \%$ in 2015. In 2005 and 2010, nearly half of Hungarians were "not very satisfied", while in 2015 it fell to $35 \%$. The share of people who were "fairly satisfied" increased over time, from only $25 \%$ in 2005 to $34 \%$ in 2015 .

In the case of Lithuania, its positions in the HDI and Eurostat ranks were not uniform. Regarding the survey on satisfaction with life, its situation was similar to Hungary's. "Very satisfied" Lithuanians increased from 9\% in 2005 to $17 \%$ in 2015 . The same was for those who were "fairly satisfied", rising from 44\% in 2005 to $57 \%$ in 2015 . The share of Lithuanians "not very satisfied" decreased from $34 \%$ in 2005 to $21 \%$ ten years later. Regarding the satisfaction with democracy, Lithuania had the worst results out of the five countries. Those "not at all satisfied" made up $22 \%$ in $2005,28 \%$ in 2010 , and $16 \%$ in 2015 . Around $50 \%$ of Lithuanians were "not very satisfied" with the democracy in their country in all years. Fortunately, the share of those "fairly satisfied" with it increased from 19\% in 2005 to $32 \%$ in 2015 , although it remained the worst result among the five countries. 
Last but not least, Poland's results in the HDI and Eurostat ranks were not uniform in the 2005 rankings, but steadily came closer to be the same in 2015 . In the case of the survey on satisfaction with life, Poland performed as the second or third best, depending on the year, and so better than in the case of the HDI or Eurostat data. Around 15\% of Poles were "very satisfied" with their lives each year, while the share of those "fairly satisfied" steadily increased from $55 \%$ in 2005 to $67 \%$ in 2015 . The share of people "not very satisfied" with their lives decreased from $24 \%$ to $15 \%$. Poland's results regarding the questionnaire on satisfaction with national democracy were also fairly good compared to the other countries. The share of Poles "not at all satisfied" fell from $26 \%$ in 2005 to $10 \%$ ten years later, and those "not very satisfied" reached $41 \%$ in 2005 but only $29 \%$ in 2015 . The share of people "fairly satisfied" increased well, to 50\% in 2015, and all in all, Poland's situation regarding the state of democracy in the subjective opinion of its citizens looked the best out of the group.

This comparison leads to a few conclusions. Firstly, the results of the HDI and Eurostat data were, in many cases, unanimous, especially regarding the Czech Republic and Estonia. This was partly true for Poland as well, because the differences between the results from the HDI and Eurostat diminished, resulting in the country having the same rank in both datasets in the last analyzed year. What is more, the public opinion surveys also corresponded in part to the data from the HDI and Eurostat. In the case of the surveys concerning happiness and satisfaction with life, the results were more or less comparable to the performances of the countries according to the two indicators. As for the survey on satisfaction with national democracy, the analyzed countries did visibly worse than compared to the HDI, Eurostat, or two other surveys. This can be an indication that a variable connected to democratic values and the state of democracy in a country should be incorporated into the measurement of economic development, as it is not part of the HDI, nor was it taken into account in the analysis of the Eurostat data.

Thus, it cannot be said with definite certainty that in light of this analysis, the Human Development Index is the best measure of economic development or that it describes the reality in the most suitable manner. However, considering the research and criticisms on this subject, it does appear to be a sufficient source of knowledge about the level of a country's potential development.

\section{Conclusion}

This article attempted to discuss the most important issues related to economic development and its measurement, with significant attention paid to Amartya K. Sen's capabilities approach and the Human Development Index. The presentation of this subject has proven that it is a complex and interrelated matter, which in turn requires caution when drawing conclusions.

Summing up this paper, it is essential to keep in mind that the Human Development Index has flaws and there has been some well-founded criticism of its methodology. However, it is one of the very few tools which aim at a comprehensive measure of economic 
development. The findings of this study are ambiguous because, in the case of some countries, such as the Czech Republic and Estonia, the HDI has been demonstrated to be a reliable source of information on their level of development, yet, the results for the remaining three countries were not consistent.

This dissertation has its limitations, such as issues with accessible data. Due to the fact that not all variables, which might be significant for the evaluation of the economic development of a given country, are gathered by the national statistical offices or Eurostat, there were limitations as to what indicators were to be used in the analysis. Another limitation is the scope of research, as economic development is a complex subject and involves multiple variables and interrelations with other fields, which hinders effective study. This implies that there is also an opportunity to expand this research, regarding, for example, the importance of the state of democracy for economic development. In this study, the findings on subjective feelings about national democracy were not in line with the level of economic development of these countries, and this matter could be explored, especially in regard to Sen's approach. As economic development, and the broader concept of human development, is still a subject of academic discussion, and economists are not unanimous on this subject, it can thus be further investigated in many respects.

\section{References}

Dzionek-Kozłowska, J., \& Matera, R. (2016). O poszukiwaniu przyczyn bogactwa i nędzy narodów w teorii Darona Acemoglu i Jamesa A. Robinsona. Gospodarka Narodowa, 5, 5-26.

Eurobarometer, European Commission. http://ec.europa.eu/commfrontoffice/public opinion/index. $\mathrm{cfm} /$ Chart/index

European Quality of Life Surveys, European Foundation for the Improvement of Living and Working Conditions. https://www.eurofound.europa.eu/surveys/european-quality-of-life-surveys

Eurostat. http://ec.europa.eu/eurostat/data/database

Grady, D. (2012, 7 March). Exercising an aging brain. New York Times. https://www.nytimes. com/2012/03/08/business/retirementspecial/retirees-are-using-education-to-exercise-an-aging-brain.html

Gray, A. (2001). Definitions of crowding and the effect of crowding on health. New Zealand Ministry of Social Policy. https://www.msd.govt.nz/documents/about-msd-and-our-work/publications-resources/archive/2001-definitionsofcrowding.pdf

Hou, J., Walsh, P.P., \& Jing Z. (2015). The dynamics of Human Development Index. Social Science Journal, 52(3), 331-347.

Kelley, A.C. (1991). The human development index: 'handle with care'. Population and Development Review, 17(2), 315-324.

Klugman, J., Rodríguez, F., \& Choi, H.-J. (2011). The HDI 2010: new controversies, old critiques. Journal of Economic Inequality, 9(2), 249-288.

Kovacevic, M. (2010). Review of HDI critiques and potential improvements. Human Development Research Paper, 33.

Noorbakhsh, F. (1998). The Human Development Index: some technical issues and alternative indices. Journal of International Development, 10, 589-605. 
Perkins, D. H., Radelet, S., Lindauer, D. L., \& Block, S. A. (2013). Economics of Development ( $7^{\text {th }}$ ed.). New York: W.W. Norton \& Co.

Sagar, A., \& Najam A. (1998). The Human Development Index: A Critical Review. Ecological Economics, 25(3), 249-264.

Sen, A.K. (2000). Development as Freedom. New York: Anchor Books.

Todaro, M.P., \& Smith S. C. (2015). Economic Development (12 ${ }^{\text {th }}$ ed.). Pearson Education.

United Nations Development Programme, Human Development Report 1990, 2006, 2007/8, 2009, 2010, 2011, 2013, 2014, 2015, 2015.

United Nations, Human Development Data (1990-2015). http://hdr.undp.org/en/data

UNODC. (2011). Global Study on Homicide. 